\title{
Cancer cells are selectively eliminated through UPR driven apoptosis during treatment with Aquilegia nivalis extracts
}

Nazia Hilal

University of Kashmir, Srinagar

Ozaira Qadri

University of Kashmir, Srinagar

Irshad A Nawchoo

University of Kashmir, Srinagar

Seema Akbar

Regional Research Institute of Unani Medicine, University of Kashmir Campus

Khalid Majid Fazili ( $\sim$ fazili@kashmiruniversity.ac.in )

University of Kashmir, Srinagar

\section{Research Article}

Keywords: Aquilegia nivalis, UPR, IRE1a, XBP1, elF2a, ATF4, Apoptosis

Posted Date: March 10th, 2021

DOI: https://doi.org/10.21203/rs.3.rs-234542/v1

License: (c) (1) This work is licensed under a Creative Commons Attribution 4.0 International License. Read Full License 
1 Cancer cells are selectively eliminated through UPR driven apoptosis during

2 treatment with Aquilegia nivalis extracts

3 Nazia Hilal ${ }^{1 \#}$, Ozaira Qadri ${ }^{1}$, Irshad A Nawchoo ${ }^{2}$, Seema $\mathrm{Akbar}^{3}$ and Khalid Majid

4 Fazili $^{*}$

5

$6{ }^{1}$ Department of Biotechnology, University of Kashmir, Srinagar-190006, Jammu and

7 Kashmir

$8 \quad{ }^{2}$ Department of Botany, University of Kashmir, Srinagar- 190006, Jammu and Kashmir

$9{ }^{3}$ Regional Research Institute of Unani Medicine, University of Kashmir, Srinagar-

10190006 , Jammu and Kashmir

11

12

13

14

15

16 \# Current address

17 Department of Biochemistry and Molecular Genetics

18 University of Illinois, Chicago

19

20

$21 *$ Correspondence:

22 Dr. Khalid Majid Fazili, PhD

23 Professor, Department of Biotechnology

24 University of Kashmir, Srinagar-190006, Jammu and Kashmir

25 Tel: +91-9419003881

26 Email: fazili@kashmiruniversity.ac.in 
ABSTRACT:

Background

Aquilegia nivalis Flax Jackson, also called Aquilegia vulgaris sub sp. nivalis (Bak.) Brühl or columbine, locally known as "Zoe-neel”, is a wild edible plant traditionally used as an anti-inflammatory medicine by the local nomadic tribes inhabiting the Himalayas of Jammu and Kashmir. The plant has been used as herbal medicine since middle ages in treating ailments that include chronic rhinitis and various infectious diseases. The extracts from the plant possess antioxidant properties and have been reported to be hepatoprotective in rats. Our preliminary studies, however pointed to hitherto unexplored anti-apoptotic potential of the plant which lead us to carry the in-depth study using breast cancer cell lines to validate its anti-cancerous properties and explore the affected pathways.

Methods

MTT assay was used to draw the dose response curve and evaluate the effect of increasing concentrations of the extract on cell lines to determine the appropriate dosage to be used for further experimentation. DNA fragmentation analysis was followed through gel electrophoresis and DAPI staining was pursued by phase contrast microscopy to study apoptosis. Quantitative PCR was used to study the expression of UPR signaling and RIDD markers at the level of mRNA. Western blot analysis was used in studying the expression of the various markers of the signaling pathways. The cell cycle analysis was carried out using flow cytometry.

\section{Results}

MTT assay revealed that the methanolic extract of the plant (ANME) was selectively cytotoxic to various cancer cell lines as revealed by lower IC50 values relative to normal cell lines. The results of cell cycle analysis were similar as ANME caused Sub G1 arrest of the cell cycle. DNA fragmentation analysis, DAPI staining and western blot analysis 
53 for PARP and caspases revealed that the extract selectively induced apoptosis in cancerous cell lines. UPR markers p-Ire1 $\alpha$ and Xbp1 splicing were consistently alleviated in a dose dependent manner, the rate of phosphorylation of eIF2a and ATF4 also decreased with increasing concentration of ANME. The RT PCR results of the RIDD marker, Blos1S1 revealed a similar dose dependent association. The methanolic extract was especially chosen for it could be easily internalized by the cells and any resultant potential bioactive compounds could gain access to the cells because of their hydrophobic nature.

\section{Conclusion}

Our results suggest that ANME causes deactivation of UPR signaling pathway facilitating apoptosis selectively in cancerous cells, paving the way forward for a novel approach in cancer therapeutics.

Keywords: Aquilegia nivalis, UPR, IRE1 $\alpha$, XBP1, eIF2 $\alpha$, ATF4, Apoptosis

\section{Abbreviations:}

UPR, Unfolded protein response: ATF4, Activating transcription factor 4: ATF6, Activating transcription factor 6: GADD34, Growth arrest and DNA damage 3: XBP1, X-box binding protein 1: ANME, Aquilegia nivalis methanolic extract : RIDD, Regulated IRE1-dependent decay of mRNA

\section{Introduction}

The exploration of natural products offers great opportunity to researchers in medical sciences to identify and explore nature friendly therapeutic agents relevant to different diseases. Aquilegia nivalis is a traditional indigenous herb found in higher altitudes of Himalayas ${ }^{1}$. The plant has been traditionally used in treatment of Asthma and as an antiinflammatory agent. It is also used as a remedy for many ailments including chronic rhinitis and various infections ${ }^{2}$. The extracts of the plant [plant extract] have shown hepatoprotective effects in mice. ${ }^{3}$ Several studies have shown the anti-oxidant role of the 
plant. ${ }^{4,5}$. Despite of its well-known anti-inflammatory and anti-oxidative properties, and the fact that the plant has been used for a long time as a traditional therapeutic agent in treating several disorders like bronchitis and bowel disorders, the plant has not been explored to its full potential. No study has been carried out to find its molecular targets and the mode of action. The plant is being extensively used by the nomadic tribes inhabiting the Himalayan ranges in Jammu and Kashmir. Some studies have suggested the antiproliferative and pro-apoptotic activities of the plant ${ }^{6}$. Our preliminary data indicated that the plant extracts were selectively toxic to cancerous cells, so the current study was carried out to validate the antiproliferative potential of the plant and explore its molecular targets in the cell. The study revealed that the methanolic extract of the plant affected UPR signaling and RIDD pathways.

The unfolded protein response is a defensive mechanism that gets activated under stressful conditions to restore homeostasis, during prolonged stress however, when restoration becomes difficult, it promotes apoptosis ${ }^{7}$. The synthesis and trafficking of nearly one-third of the total protein in eukaryotic cells is synchronized by Endoplasmic Reticulum $^{8,9,10}$. The ER is responsible for tuning up protein homeostasis ${ }^{11}$ and ensures the release and bartering of properly folded proteins after post-transcriptional and posttranslational modifications through various mechanisms existing within the organelle. Despite this, a colossal amount of proteins transiting via ER are not properly folded and may be degraded by ER-associated degradation (ERAD) system ${ }^{11}$. The perturbations in 99 influx to efflux ratios of proteins within the ER compartment coupled with accumulation 100 of misfolded proteins causes ER stress that is combated through a defensive mechanism 101 known as Unfolded Protein Response ${ }^{12,13}$. UPR determines the cellular fate either 102 towards survival or death depending upon the severity of stress and primarily operates via 103 three axis namely; Ire1- $\alpha / \mathrm{Xbp}-1$, PERK/eIF2 $\alpha$ and ATF6 ${ }^{7,14,15}$ 
104 Tumor cells experience increase metabolic activities and high proliferation rates, which

105 in turn demands boisterous ER and secretory mechanisms. This boosted demand for

106 secretory functions is likely to trigger a mid-course correction of ER homeostasis and

107 consequently ends up in basal or constitutive UPR induction. Ire1 $\alpha$ mutations have been

108 implicated in many human cancers on the basis of genome wide screening with roles in

109 tumor growth, metastasis and chemo-resistance ${ }^{16,17,18 .}$ A compromising tumor growth and

110 survival is observed when $\mathrm{Xbp} 1$ expression is thwarted, inhibiting Ire1/Xbp1 axis

111 impinge the coherence of the secretory tissues ${ }^{19-23}$. PERK pathway in tumor cells either

112 facilitates their survival or suppresses their progression. PERK branch confers oncogenic

113 transformation by promoting myc induced autophagic pathways ${ }^{24,25}$. CHOP (an apoptosis

114 mediator) suppresses the tumor progression thus chop deletion has tumor progression

115 phenotype in lung cancer. ${ }^{26,27}$

116 Many pathological complications are associated with the disturbance in the protein

117 folding machinery, aggregation and concurrent ER stress ${ }^{7,28}$. Various therapeutic drugs

118 induce ER stress and destine the cells to apoptosis ${ }^{29}$. It is possible that an optimum level

119 of ER stress and UPR signaling is induced under tumor microenvironment is necessary

120 for cancer survival and progression, but exacerbating the stress levels beyond the

121 handling capacity can drive cancer cells toward death. UPR signaling can be targeted in

122 cancer treatment in both ways, that is, either by inducing a high level of stress in the pre-

123 existing stress microenvironment of tumor or by preventing activation of UPR that is

124 beneficial for cancer progression and drug resistance, making them sensitive to other

125 chemotherapeutic drugs.

126 In the above context, our study becomes important as it reflects the potential effects of

127 the plant extract to selectively induce apoptosis in cancerous cells coupled with

128 deactivation of UPR and RIDD signaling pathways. 
MATERIALS AND METHODS:

\section{Chemicals}

132 Tunicamycin was purchased from EMD Millipore (Darmstadt, Germany).Dulbecco's

133 modified Eagles medium (DMEM) and Fetal bovine Serum (FBS) were purchased from

134 GIBCO (St. Louis, Mo, USA). Bicinchoninic acid (BCA) protein assay kit was purchased

135 from pierce (Rockford, USA). and 3-(4,5-dimethylthiazole-2-yl)-2,5, diphenyltetrazolium

136 bromide (MTT) were purchased from Sigma-Aldrich (St. Louis, Mo, USA).

\section{Preparation of methanolic fraction of Aquilegia nivalis}

138 Aquilegia nivalis was collected between July and August 2016, from several regions of 139 Kashmiri Himalayas. The plant was identified and deposited in the KASH Herbarium 140 under voucher specimen No.2716-(KASH). Whole Plant parts were washed with distilled 141 water to remove residues and shade dried. The dead parts were removed, and healthy 142 ones were grounded to powder, preserved for extraction. ANME (Methanolic fraction of 143 Aquilegia nivalis) was prepared from dried and coarse powder using methanol as a 144 solvent. Hot extraction was carried out in a Soxhlet apparatus taking Plant powder and 145 solvent in ratio of 1:6. The extract was filtered and evaporated to dryness and the residues 146 were weighed. The extract solutions obtained were combined and evaporated to dryness 147 by a rotary evaporator under vacuum at $65^{\circ} \mathrm{C}$. The yield was calculated by dividing the 148 mass of recovered dry extract (mr) by the initial mass of powder (mi).

149 Yield $(\%)=\mathrm{mr} / \mathrm{mi} \times 100 \%$

150 This residue was then dissolved in $50 \%$ DMSO to make the concentration of $100 \mathrm{mg} / \mathrm{mL}$ 151 working stock and stored at $4^{\circ} \mathrm{C}$. The working concentration of DMSO used was $2 \%$ for 152 experiments. 
157 Breast cancer cell lines, MDAMB-231 and MCF7 and neuronal cell line U87MG 158 glioblastoma, and the normal human embryonic kidney cells, Hek293T were purchased

159 from National Centre for Cell Science (NCCS, Pune).

\section{Antibodies and Western blot analysis}

161 SDS-Polyacrylamide gel electrophoresis and Western blotting were performed by usual 162 procedures. All the four cells were seeded at $1 \times 10^{6}$ cells/well in a $100 \mathrm{~mm}$ culture dish 163 and incubated for $24 \mathrm{~h}$. The incubated cells were treated with varying concentrations of 164 ANME with or without $6 \mu \mathrm{M}$ of tunicamycin for $24 \mathrm{~h}$. The cells were harvested in 165 phosphate buffered saline (PBS) containing $0.1 \%$ protease inhibitor cocktail. The primary 166 and secondary antibodies used were as follows. Rabbit polyclonal antibodies against

167 Phosphorylated version of Inositol requiring enzyme (Ire1 $\alpha$ ), X-box binding protein 168 spliced (sXbp1), Activating transcription factor 4 (ATF4), Phosphorylated version of 169 alpha subunit of eukaryotic initiation factor (p-eIF2 $\alpha$ ) and GAPDH were obtained from 170 Cell Signaling Technology (Danvers, MA). Alkaline Phosphatase linked secondary anti171 Rabbit antibody was purchased from Sigma-Aldrich (St. Louis, Mo, USA). BCIP (5172 Bromo-4-chloro-3-indolylphosphate) and NBT (Nitro blue tetrazolium) were purchased 173 from Sigma-Aldrich (St. Louis, Mo, USA).

\section{Real-time quantitative PCR for analysis}

175 The cells were seeded at $1 \times 10^{6}$ cells/well in a $100 \mathrm{~mm}$ culture dish and incubated for 24

176 h. The incubated cells were treated with varying concentrations of ANME with or 177 without $6 \mu \mathrm{M}$ of tunicamycin for $24 \mathrm{~h}$. RNA was extracted from the harvested cells using an RNeasy kit (Qiagen, Hilden, Germany). RNA was reverse-transcribed to synthesize cDNA using a Revert Aid First strand cDNA synthesis kit (Thermo scientific) as per

180 manufacturer's protocol, and used in duplicate for quantitative real-time PCR analysis 181 using the SYBR Green reagent system Applied Biosystems 7500 Fast Real-Time PCR 
182 System (Applied Biosystems, Foster City, CA). Relative quantities of amplified cDNAs

183 were then determined using SDS software (Applied Biosystems) and normalized to $\beta$ -

184 actin mRNA.

185 The following primers were used:

$186 \quad$ ATF4

187 5'-TTC CTG AGC AGC GAG GTG TTG -3'(sense)

188 5'-TCCAATCTGTCCCGGAGAAGG-3 (antisense)

189 CHOP

190 5/-CTTGGCTGACTGAGGAGGAG-3/(sense)

191 5/-TCACCATTCGGTCAATCAGA-3/(antisense)

192 Spliced XBP1

193 5/-CTGAGTCCGAATCAGGTGCAG-3/(sense)

194 5/-ATCCATGGGGAGATGTTCTGG-3/(antisense)

$195 \boldsymbol{\beta}$-actin,

196 5/-TCATCACCATTGGCAATGAG-3/ (sense)

197 5/-CACTGTGTTGGCGTACAGGT-3/ (antisense)

198 Quantification of western blot

199 The intensity (area x optical density) of the individual bands on Western blots was

200 measured by using ImageJ and normalized either to GAPDH or, in the case of a 201 phosphoprotein, to its total protein as mentioned.

202 Cell viability assays

203 Cell viability measurements for ANME were done using MTT assay. Cell were seeded in 204 96-well plate at $10^{4}$ cells per well. Different concentrations of extract $(1-2000 \mu \mathrm{g} / \mathrm{mL})$ 205 were added to each well incubated for $24 \mathrm{~h}$. Next day $10 \mu \mathrm{L}$ of $5 \mathrm{mg} / \mathrm{mL}$ MTT were 206 added to each well and incubated for $4 \mathrm{~h}$. The formazan crystals were dissolved by 207 adding $100 \mu \mathrm{L}$ of DMSO to each well. Absorbance was measured at $560 \mathrm{~nm}$ with 
208 Universal Microplate Reader (Bio-Tek Instruments, USA). The reference wavelength 209 was set at $650 \mathrm{~nm}$. The cell viability of untreated cells was considered $100 \%$.

\section{Cell cycle analysis by flow cytometry}

211 The cells were seeded at $1 \times 10^{6}$ cells/well in a $100-\mathrm{mm}$ culture dish and incubated for 24

$212 \mathrm{~h}$. The incubated cells were treated with ANME $(50 \mu \mathrm{g} / \mathrm{mL}$ for MDAMB231 $100 \mu \mathrm{g} / \mathrm{mL}$ 213 for MCF7 and $25 \mu \mathrm{g} / \mathrm{mL}$ for U87MG), with or without $6 \mu \mathrm{M}$ of Tm for $24 \mathrm{~h} .$. Media was 214 collected in $15 \mathrm{ml}$ tubes and cells were washed with PBS containing $0.1 \%$ EDTA. 215 Washing solution was also collected. PBS-EDTA was added to the plates followed by 216 incubation at $37{ }^{\circ} \mathrm{C}$ for 5-10 minutes. Cells were collected, pipetted up and down and 217 collected in same tubes. Tubes were centrifuged at $1000 \mathrm{~g}$ for 5 minutes followed by 218 washing in PBS-Serum (1\% serum) and centrifuged again at 1000g. Afterwards, cells 219 were resuspended in $0.5 \mathrm{ml}$ PBS. For fixing, $5 \mathrm{ml}$ ethanol was added drop wise while 220 vertexing the cells. Cells were then stored in deep freezer for FACS analysis. For FACS 221 analysis, fixed samples were centrifuged at $1000 \mathrm{~g}$ for 5 minutes and washed with PBS222 serum followed by resuspension in Propidium Iodide-RNAse solution $(50 \mu \mathrm{g} / \mathrm{ml}$ 223 propidium iodide, $10 \mathrm{mM}$ Tris $\mathrm{pH} 7.5,5 \mathrm{mM} \mathrm{MgCl} 2$ and $20 \mu \mathrm{g} / \mathrm{ml}$ RNase A). Finally, 224 samples were acquired and analyzed by using BD FACS machine and BD FACS Suite 225 software. The experiments were done in triplicates. For analysis outliers were discarded.

\section{Statistical analysis}

227 The GraphPad Prism®6 software (GraphPad software Inc.) was used for statistical 228 analysis. All experiments were repeated independently three times. IC50 values were also 229 calculated using non-linear regression analysis with GraphPad Prism®6 software.

\section{$230 \quad$ Results}

\section{ANME display cytotoxicity against cancer cell lines in vitro}

232 MTT viability assay on HEK293T human embryonic kidney cells, MDAMD-231 breast

233 cancer,MCF7 breast cancer and U87 glioblastoma cells were done separately with a 
range of concentrations of ANME between 1 to $2000 \mu \mathrm{g} / \mathrm{ml}$. ANME alleviated cell viability in a dose dependent manner. All the experiments were performed in triplicate. IC50 values were calculated by non-linear regression analysis using Graph Pad Prism values of ANME in HEK293T human embryonic kidney cells, MDAMD-231 breast 239 cancer, MCF7 breast cancer and U87 glioblastoma were $532.1 \mu \mathrm{g} / \mathrm{mL}, 100.2 \mu \mathrm{g} / \mathrm{mL}$, $240205.6 \mu \mathrm{g} / \mathrm{mL}$ and $42.23 \mu \mathrm{g} / \mathrm{mL}$, respectively (Fig.1A-D). Higher concentrations of the extract presented with vivid morphological changes under phase contrast microscope.

242 The most marked changes were cell shrinkage and extensive cell detachment from cell 243 culture substratum.

\section{ANME displayed different cell cycle responses}

245 The propidium iodide based cell cycle analysis by flow cytometry revealed that the cell 246 lines responded differently to the treatment with some cells undergoing significant cell 247 death, as indicated by an increase in SubG1 peak, whereas others not showing any 248 appreciable change in the cell cycle profile. HEK 293T (human embryonic kidney) cell 249 line which is a normal cell line didn't show an appreciable increase in SubG1 peak (Fig. 2502 A). U87MG (human glioblastoma) cell line showed moderate response to ANME treatment (Fig. 2 B). MDAMB231 and MCF7 (Breast cancer) cell lines, however,

252 showed a remarkable increase in SubG1 (Fig. 2 C-D). This indicated that the breast 253 cancer cell lines were highly sensitive to ANME treatment. These results show that 254 different cell types respond differently to ANME, whereas different cancer cell lines are 255 sensitive to a varying degree, the response ranging from low to high cell death, the normal cell lines did not show any significant effect.

\section{ANME inhibits tumor cell growth in vitro by induction of apoptosis}

258 The antiproliferative potential of ANME was evaluated in HEK293T human embryonic 259 kidney cells, MDAMD-231 breast cancer, MCF7 breast cancer and U87 glioblastoma. As 
shown in Fig 1A IC50 values of HEK293T human embryonic kidney cells, MDAMD-

231 breast cancer, MCF7 breast cancer and U87 glioblastoma for ANME treatment were $532.1 \mu \mathrm{g} / \mathrm{mL}, 100.2 \mu \mathrm{g} / \mathrm{mL}, 205.6 \mu \mathrm{g} / \mathrm{mL}$ and $42.23 \mu \mathrm{g} / \mathrm{mL}$, respectively revealing a

263 relatively higher sensitivity of cancer cell lines. Also there was a general SubG1 arrest in the cells. The Ladder assay revealed a time-dependent increase in DNA fragmentation on treatment with ANME as observed on DNA-gel electrophoresis. DNA extracted from cells treated with ANME showed an increased generation of apoptotic DNA fragments as compared with solvent-treated control cells, it also displays a higher sensitivity of the cancer cell lines relative to normal cell lines.(Fig. 3A)

DAPI assay revealed apoptosis-specific features of ANME-treated cells from 0 Hours to 48 Hours. U87 MG, MDAMB231 and MCF7 on treatment with ANME showed various nuclear changes such as chromatin condensation, nuclei condensation, and nuclear degradation, however Hek293T cells did not show any signs of significant apoptotic activity. (Fig. 3B)

\section{UPR mediated onset of Apoptosis}

Since the cancerous cells are in a state of constant stress because of their high metabolic profile, controlled UPR is known to be active in these cells. So next we decided to look at the UPR signaling pathway. Figures 4-7 show the results of Western blots of various UPR signaling markers using specific antibodies. In order for us to check the pathway involved through which ANME caused the apoptosis, we checked for the global impact on proteostasis markers. The perturbation of cellular proteostasis networks by inhibition of the proteasome results in induction of an unfolded protein response ${ }^{30,31}$. Our results suggested that ANME averted UPR response in both Cancer and 293T cells, as judged by inhibition of p-Ire1 $\alpha$. Figure 4 shows the effect of tunicamycin and increasing concentrations of ANME on the expression of phosphorylated Ire1 $\alpha$. The phosphorylation of Ire $1 \alpha$ causes activation of UPR and serves as one of the first markers 
of UPR activation. As is shown in figure, ANME exposure is associated with decreasing

287 concentration of P-Ire1 $\alpha$ in all the four cell types (Fig. 4 A-D) reflecting deactivation of 288 the kinase associated IRE1 signaling of UPR. Xbp1s is another downstream marker of 289 the same pathway. Figure 5 shows the effect of tunicamycin and increasing 290 concentrations of ANME on Xbp1 splicing. ANME inhibits the splicing reaction in all 291 the cell types as indicated by reduced expression of XBp1-s.(Fig.5 A-D), the total 292 phosphorylation level of Ire1 $\alpha$ protein decreased, with kinetics matching the inhibition of 293 Xbp1s, consistent with a previous report ${ }^{32}$.

294 Next, we evaluated the effect on the PERK arm of UPR. Figure 6 shows the effect of 295 tunicamycin and increasing concentrations of ANME on the expression levels of p-eIF2 $\alpha$ 296 and ATF4, the downstream effector molecules of the PERK arm of UPR The expression 297 levels of both the effector molecules decreased in a concentration dependent manner on treatment with ANME (Figure 6 A-D)

299 Further we tested the effect of ANME treatment on mRNA expression levels of Xbp1 and 300 ATF4 in different cell lines. ANME significantly repressed the expression of Xbp1, a 301 downstream target of Ire1 arm, and ATF4, a downstream target of PERK arm of UPR in 302 a concentration dependent manner (Figure 7 A-C)

303 Next we checked effect of the treatment on RIDD activity. Figure 8 shows the qRT PCR 304 based mRNA expression of BLOC1S1 (BLOS1) which is used as a marker for RIDD 305 activity. Treatment with increasing concentrations of the extract shows a 2-3-fold 306 increase in the expression levels in all the cell lines tested (Figure 8 A-C) indicating that 307 the RIDD arm of UPR is also decreased. To check whether ANME directly inhibits Ire1 $\alpha$ 308 activity, we tested ANME inhibition on RIDD marker BLOC1S1 (BLOS1) which are 309 considered as standard markers for testing RIDD activity. ${ }^{33,34} \mathrm{We}$ found that ANME 310 inhibit Ire1 $\alpha$ activity in vitro for RIDD (Fig 8 A-C), indicating the role of ANME on in 311 apoptosis is through the RNAse activity of Ire1 $\alpha$ in a dose-dependent manner. 
312 ANME-induced apoptosis of tumor cells is associated with dual inhibition of 313 Ire1/xbp1 and PERK/ATF4 and activation of Caspases

314 Following DNA ladder assay and cell cycle analysis, we probed the effect of ANME on 315 caspase and PARP. Western blots with PARP and caspase antibodies were used to probe 316 the effect of the treatment with different cell lines. The results are shown in Figure 9.

317 HEK293T cell lines did not show any apoptotic signals as revealed by the absence of 318 caspase3 and PARP (Fig.9A), however, other cell lines U87MG, MDAMB231 and 319 MCF7 clearly show the onset of apoptosis in a concentration dependent manner (Figure 9

320 B,C). This was consistent with the results obtained in DNA fragmentation assay and cell 321 cycle analysis. This can be attributed to the fact that in HEK293T cells the Unfolded 322 Protein Response is rescued due to ANME treatment resulting in restoration of the in 323 milieu proteostasis. However, the apoptotic death in other cell lines that are cancerous in 324 nature is ascribed to uncompromised ER stress associated with activation of the RIDD 325 pathway. These results suggested the pro-apoptotic potential of ANME is attributed to the 326 dual inhibition of Ire1/xbp1 and PERK/ATF4 axis that renders the cancer cells vulnerable 327 to apoptotic death via activation of caspases.

\section{Discussion}

329 Aquilegia nivalis traditionally used in treatment of asthma and ailments like chronic 330 rhinitis and infections with documented hepatoprotective properties offers great promise 331 in disease therapeutics. The plant though has not been explored to its full potential. The 332 extracts of the Aquilegia species have been shown to display hepatoprotective effects in 333 mice. ${ }^{3,35,36}$ Several studies have shown the anti-oxidant activities of the plant. The plant 334 has been used as a herbal medicine since ages with proven efficacy in diseases like 335 chronic rhinitis, and as anti-inflammatory in infections. ${ }^{4,5,36}$ However detailed studies 336 validating the therapeutic potential of the plant and about the mode of its action are 337 lacking. This study was conducted to validate its antiproliferative effects and evaluate its 
target signaling pathways as anti-inflammatory activities in certain plants are reported to be coupled with anti-proliferative pro-apoptotic activities ${ }^{6 .}$ Our preliminary investigations on the extracts of the plant showed that the methanolic extract of the plant selectively acted on cancer cells. Based on this we carried in-depth study on several cancer cell lines

342 with promising results. This study established that the extract from the plant selectively 343 induced the apoptotic pathways leading to cell death in cancerous cells. The methanolic 344 extract from the plant was particularly chosen for it displayed higher activity and for the 345 fact that it could easily be internalized by the cells. Any potential bioactive compounds 346 could also be easily accessible to the cells because of their hydrophobic nature. In the 347 ladder assay, DNA fragmentation followed by gel electrophoresis revealed generation of 348 apoptotic fragments selectively in cancerous cells and also an alleviation of apoptosis is 349 observed on treatment with the methanolic extract of Aquilegia nivalis in a concentration 350 dependent manner. Cell cycle analysis with flow cytometry displayed a differential 351 response of the cells, whereas subG1 arrest was observed in all the cancerous cells but 352 with variations in the subG1 peak, the normal cells behaved differently with no subG1 353 peak observed. DNA fragmentation and cell cycle arrest have been considered a hall 354 mark of apoptosis ${ }^{33}$. Other pro-apoptotic markers that were tested include Caspase-3 and 355 PARP which showed comparable results with different cancerous cell lines experiencing 356 apoptosis to variable degrees, though no significant amount of apoptosis is seen in 357 normal cell lines. Several recent studies have demonstrated the proapoptotic and anti358 apoptotic potential of plant derived extracts ${ }^{34,37,38}$. The methanolic extracts 359 of Andrographis nallamalayana Ellis have been shown to induce apoptosis in various 360 melanoma cell lines ${ }^{6}$. Similarly extracts derived from Menyanthes trifoliata L. are 361 reported to induce apoptosis in human cancer cells affecting Caspase 3, PARP and other 362 pro apoptotic markers in a similar fashion ${ }^{39}$. Next we tried to understand the affected 363 pathways. Cancer cells are under constant stress due to their high metabolic load, and the 
link between the cellular stress response and apoptosis is relatively well established.

365 Many studies have linked modulation of unfolded protein response to apoptosis ${ }^{40,41}$.

366 Under hypoxia, cells have been found to show upregulation of hypoxia induced proteins

367 and UPR signaling cascade that differ in normal and cancerous cell lines, however, the

368 exact mechanism deciding about the cell fate is not clearly understood ${ }^{42}$. Next we

369 checked the expression of downstream molecules of the Ire1 and PERK arms of the UPR

370 signaling pathway as well as BLOS1, a marker for RIDD activity.

371 It was found that treatment of cells with the methanolic extract of the plant

372 downregulated the phosphorylation of Ire1 alpha and Xbp1 splicing in a concentration

373 dependent manner. It also resulted in reduced protein expression levels of

374 phosphorylation levels of p-eIF2 $\alpha$ and protein levels of ATF4 in all four cell lines viz

375 HEK-T293, U87-MG, MCF7 and MDAMB 231. The complexity of Ire1 biology was

376 demonstrated through a recent study suggesting that modulation of Ire1 RNase activity

377 was possible through an allosteric mechanism using ATP-competitive kinase inhibitors

378 APY29 and sunitinib ${ }^{43}$. Furthermore, a peptide derived from the Ire1 kinase domain was

379 shown to stimulate Ire1 oligomerization while inhibiting the JNK activation and RIDD

380 activity of Ire $1^{44}$. Ire 1 modulators specific for either Xbp1 splicing or RIDD activity may

381 be clinically useful depending on the therapeutic intent. Protein kinase R (PKR)-like

382 endoplasmic reticulum kinase (PERK) mediates the translational control arm of the UPR

383 by enhancing phosphorylation of alpha subunit of eukaryotic Initiation Factor 2 (eIF2 $\alpha$ )

384 that kickbacks to a variety of endoplasmic reticulum stresses associated with numerous

385 diseased states. Evidences relating PERK with tumorigenesis and cancer cell survival

386 commoved our search for small molecule inhibitors.

387 The expression of Xbp1s and ATF4 was also found to be inhibited in a similar manner at 388 mRNA level. The mRNA expression of BLOC1S1, a marker for RIDD activity was

389 found to be increased on treatment with the extracts, owing to the fact that the extract was 
downregulating RIDD activities as well. This in in line with the studies carried by These results were consistent with the protein markers of UPR signaling and RIDD activity and reflected a dual modification of the signaling by ANME treatment ${ }^{45}$.

393 The unfolded protein response (UPR) serves as an adaptive mechanism to restore 394 homeostasis. When the stress prolongs and resolution becomes difficult, the UPR 395 commits the cell to apoptotic death. Here we show that in cancerous cells MDAMB-231, 396 Breast cancer cell lines, MCF7, neuronal cell line and U87MG glioblastoma, apoptotic 397 pathways are activated via modulation of Unfolded protein response that includes 398 inhibition of the Ire and PERK signaling as well as activation of RIDD signaling. These 399 results point towards the cross-regulation between the apoptotic cascade and the adaptive 400 UPR signaling in cancerous cells. Similar observations have recently been recorded with 401 studies on Ire1 mutants ${ }^{46}$.

402 An important finding of the study is that in Hek293T cells the cell death via apoptosis 403 was not evident. This may be attributed to the fact that in these cells the UPR has being 404 rescued due to ANME and the in mileu proteostasis was restored as depicted from 405 restoration of UPR markers to the basal level, and that no Caspase 3 or PARP cleavage 406 is seen in these cells. The apoptotic death in other cell lines cancerous in nature can be ascribed to the chronic stress conditions developing as a result of inhibition of the arms 408 after drug treatment that in turn increases ER stress intensity to its threshold level 409 initiating apoptosis through repression of antiapoptotic pre-miRNAs ${ }^{47,48}$ or alternatively 410 through upregulation of Casp2 ${ }^{49}$. In Hek293T cells the UPR has been rescued due to 411 ANME and the in mileu proteostasis was restored as depicted from restoration of UPR 412 markers to the basal level and also no Caspase 3 or PARP cleavage was seen in these 413 cells. A close association of Ire $1 \alpha$ activity and cell fate determination has been proposed 414 that provide evidences of Ire $1 \alpha$ being molecular switch that facilitates apoptosis during 415 prolonged ER stress. The caspase activation due to inhibition of PERK arm is in line with 
416 earlier studies wherein deletion of PERK in MEF cells subjected to prolonged hypoxia

417 has been reported to produce partial restoration of protein synthesis and enhanced

418 activation of caspases, leading to elevated levels of cell death ${ }^{50}$. Taken together our

419 results suggest that apoptosis is selectively induced in cancer cells MDAMB-231, MCF7

420 and neuronal cell line U87MG glioblastoma during treatment with Aquilegia nivalis 421 extract (ANME) coupled with modulation of the Unfolded Protein Response signaling 422 pathways with inhibition of Ire1 and PERK signaling cascades. Interestingly however the 423 treatment also resulted in deactivation of the regulated IRE1-dependent decay of mRNA 424 (RIDD). Further studies are required to understand the mechanistic basis of these effects 425 and explore the therapeutic potential of the constituent bioactive molecules.

\section{Conclusion}

427 The methanolic extracts of Aquilegia nivalis selectively target cross-regulation between 428 apoptosis and adaptive UPR signaling in cancerous cells may contain potential 429 therapeutic molecules selectively targeting cancerous cells.

\section{$430 \quad$ Declarations}

\section{Ethics approval and consent to participate}

432 Not applicable

\section{Consent for publication}

434 All authors agree to submission of the manuscript for publication to BMC 435 complementary medicine and therapies and give their consent for its publication, if 436 accepted.

\section{Availability of data and materials}

438 The datasets used and/or analyzed during the current study are available from the 439 corresponding author on reasonable request. 
443 The authors declare that they have no competing interests as defined by BMC, or other

444 interests that might be perceived to influence the results and / or discussion reported in 445 this paper.

\section{Funding}

447 The study was funded by research grants from the Ministry of Ayuerveda, Yoga nad 448 Naturopathy, Unani, Siddha and Homoaepathy (AYUSH) to KMF, Grant No. 449 Z.28015/09/2016-HPC (EMR)-AYUSH-C. NH and OQ have been the recipients of 450 Senior Research Fellowship and Junior Research Fellowship respectively from the 451 Ministry of AYUSH funded project.

\section{Author contributions}

453 Nazia Hilal, Seema Akbar and Khalid Majid Fazili were involved in the concept and 454 design of the study. The acquisition and analysis of the data was done by Nazia Hilal and 455 Ozaira Qadri. Nazia Hilal wrote the main manuscript and prepared figures, KMF revised 456 the manuscript. Irshad A Nawchoo and Seema Akbar identified and the plant and were 457 involved in extraction. All the authors reviewed and approved the manuscript. The final 458 approval of the manuscript was by Khalid Majid Fazili and Nazia Hilal

\section{Acknowledgements}

460 We acknowledge the financial support provided by grants from the Ministry of AYUSH, 461 New Delhi (No.Z.28015/09/2016- HPC (EMR)-AYUSH-C) to Khalid M Fazili. Nazia 462 Hilal and Ozaira Qadri received fellowships from the Ministry of AYUSH during this 463 project. We would also like to acknowledge Department of Biotechnology (DBT), New 464 Delhi to provide grant support (No. BT/PR7240/MED/30/915/2012) to Khalid Majid 465 Fazili. We would also like to acknowledge the FIST support (No. SR/FST/LSI-384/2008) 466 from Department of Science and Technology and the facilities extended by University of 467 Kashmir, Srinagar-190006, India 
$469 \mathrm{NH}$ has been a Ph D student and recipient of Senior Research Fellowship from Ministry of 470 AYUSH funded project TO KMF. She is currently a Post Doctoral Fellow at University of 471 Illinois, Chicago. NH is recipient of MSCA and DFG Fellowship. Ozaira Qadri is a PhD 472 student and has been the recipient of Junior Research Fellowship from Ministry of AYUSH 473 funded project sanctioned to KMF. OQ is recipient of the Senior Research Fellowship from 474 Indian Council of Medical Research. Irshad A Nawchoo is Professor of Botany and Dean, 475 School of Biological Sciences at University of Kashmir. Seema Akbar is a Scientist and 476 Director In-charge of Regional Research Institute of Unani Medicine, University of Kashmir 477 campus, Srinagar. Khalid Majid Fazili is Professor and Head of Biotechnology Department 478 and Dean School of Unani and Ayuervedic Medicine at University of Kashmir.

479

480

481

482

483

484

485

486

487

488

489

490

491

492

493 

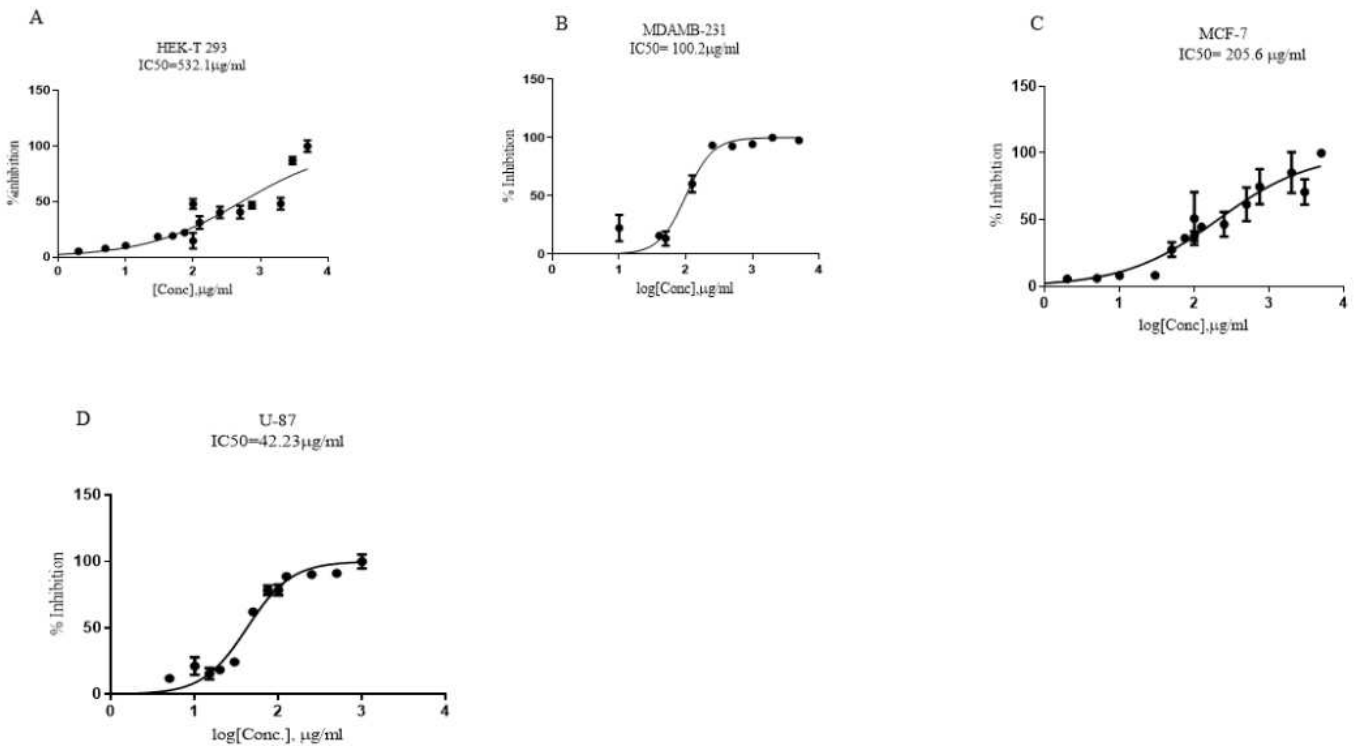

495

Figure.1: Effect of ANME on (A)HekT293 (B) MDAMB-231(C) MCF7 and (D)

497 U87MG 2 cells in various concentrations $(\mathbf{1 - 2 0 0 0} \mu \mathrm{g} / \mathrm{mL})$ after 24 hours; determined

498 using MTT cell viability assay: Dose-response curves of ANME was determined using 499 MTT cell viability assay. IC $_{50}$ values were calculated as mean values from three 500 independent experiments by nonlinear regression using Graph pad Prism®6 software.

501 Percentage inhibition of untreated cells was assumed to be zero. 
A

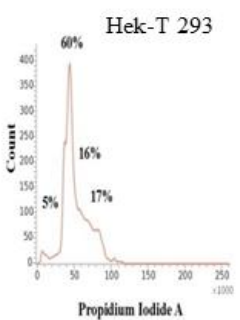

C

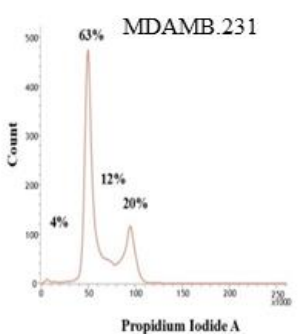

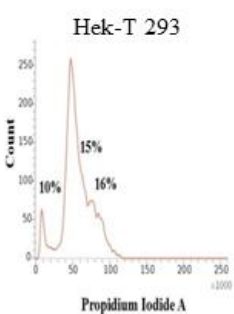

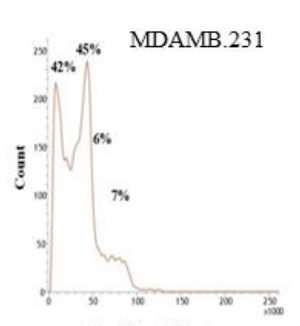

Propidium lodide A
B

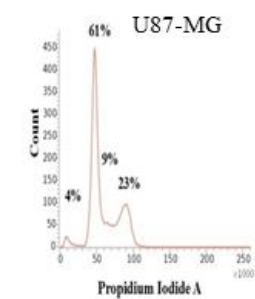

D

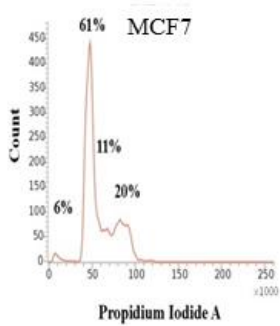

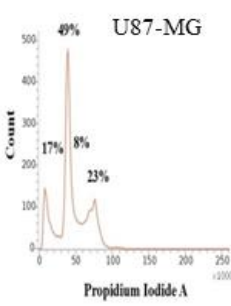

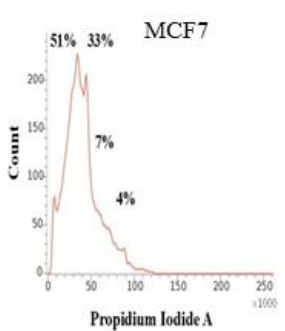

502

503

504 lines were treated with different concentrations of ANME for $24 \mathrm{hrs}$ and cells were

505 fixed and stained with propidium iodide and analyzed by flow cytometry. The mean

506 values \pm SD were calculated from three different experiments. $\mathrm{p}<0.05$ with respect to

507 control.

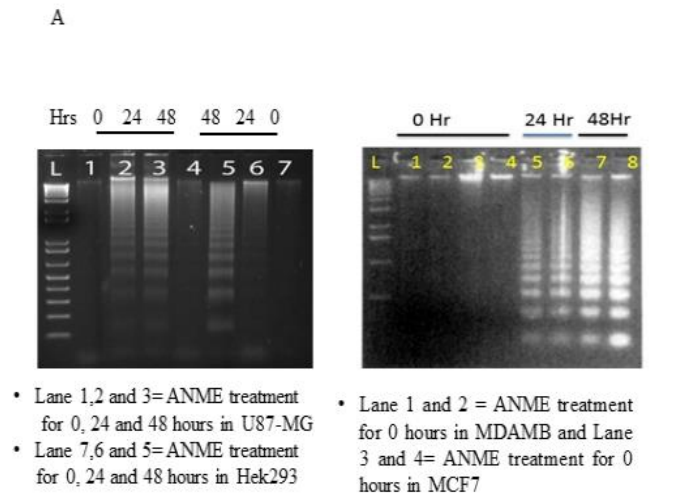

B
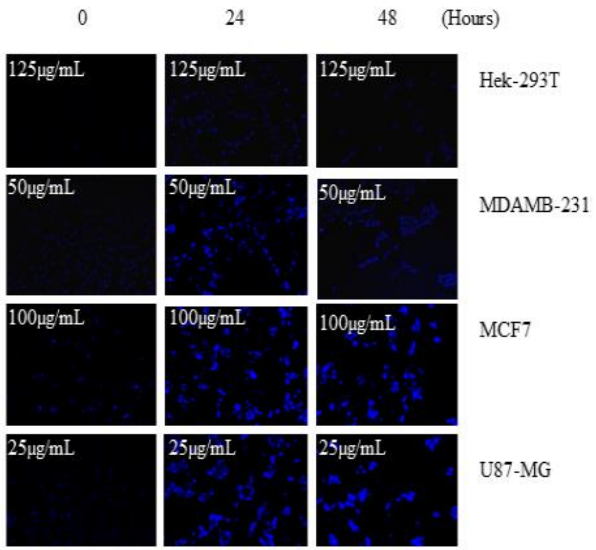

509 Figure.3: (A) Time dependent DNA fragmentation: DNA Laddering in (a) U87- MG

510 and HEK-T293 cells (b) MDAMB231 and MCF7 cells resp. ANME extract induces

511 DNA fragmentation in all the cell line panels stimulated with or without $6 \mu \mathrm{M}$ 
512 Tunicamycin(4hr) for induction of Unfolded Protein cells. The cells were treated with

513 different concentrations $(\mu \mathrm{g} / \mathrm{ml})$ of extract for every cell type for 0,24 and $48 \mathrm{~h}$. Cells

514 from each sample were harvested for DNA gel electrophoresis as described;

515 (B) Formation of apoptotic bodies in time dependent manner, DAPI staining:

516 Morphological and nuclear changes induced by ANME. HEK- T293, MDAMB, MCF7

517 and U87-MG cells after treatment with different concentration for each cell type induced

518 various nuclear changes such as chromatin condensation, nuclei condensation, and

519 nuclear degradation, as demonstrated by DAPI staining at $400 \times$ in time dependent

520 manner. However Hek293 showed only inhibition in cell growth with no signs of

521 apoptosis; ANME=Aquilegia nivalis methanolic extract.

A

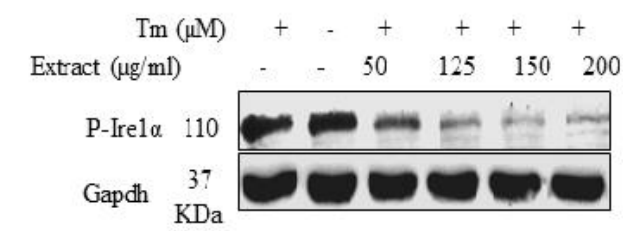

C

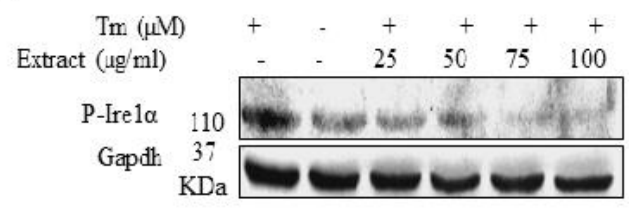

B

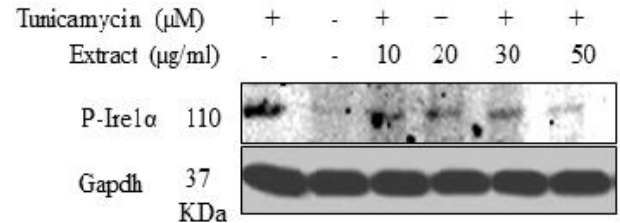

D

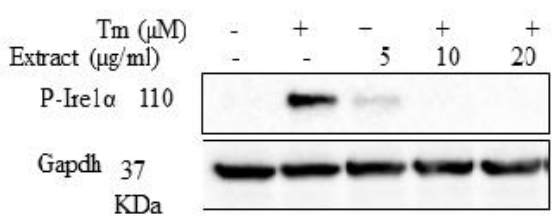

522

523

524

525

526

527

528

Figure.4: Immunoblot analysis for p-Ire1 $\alpha$ in (A) Hek293T (B) MDAMB 231(C) MCF 7 (D) U87 MG: Protein extracts of Hek T 293, MDAMB 231, MCF 7 and U87MG stimulated with or without $6 \mu \mathrm{M}$ Tunicamycin (4hr) for induction of Unfolded Protein Response followed by treatment with different concentrations in $\mu \mathrm{g} / \mathrm{ml}$ of ANME was isolated and run out for Western blotting. Blots were probed with p-Ire $1 \alpha$. GAPDH was used as loading control. Experiments were repeated three times and a representative blot is shown. 

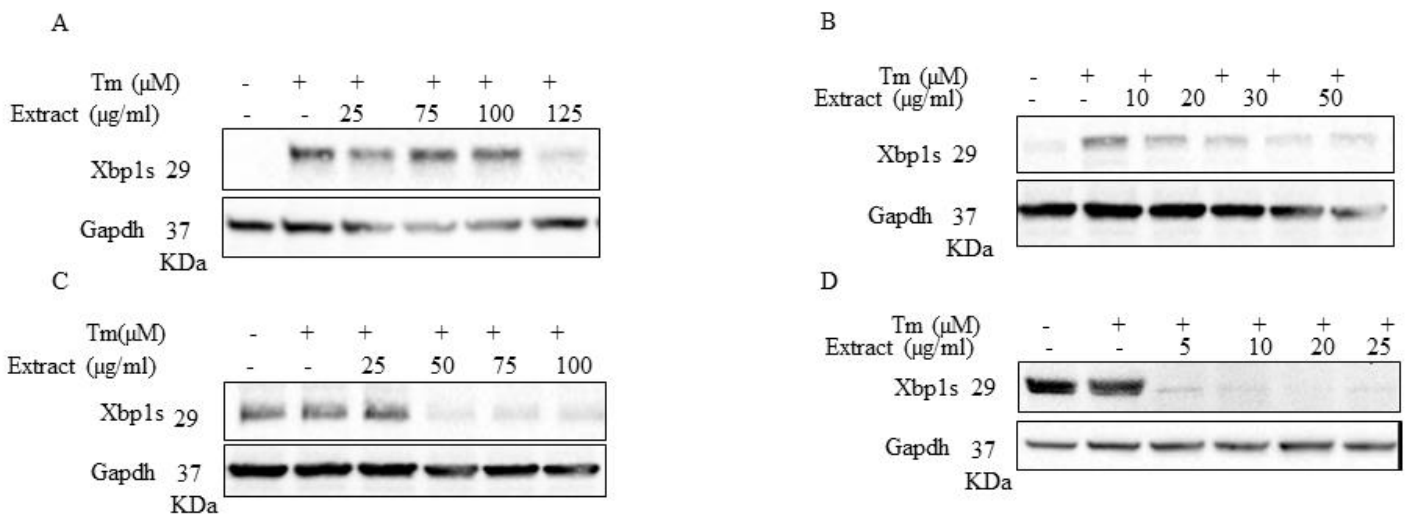

531 Figure.5: Immunoblot analysis for Xbp1-s in (A) Hek293T (B) MDAMB 231(C)

532 MCF 7 (D) U87 MG: Protein extracts of Hek T 293, MDAMB 231, MCF 7 and

533 U87MG stimulated with or without $6 \mu \mathrm{M}$ Tunicamycin (4hr) for induction of Unfolded

534 Protein Response followed by treatment with different concentrations in $\mu \mathrm{g} / \mathrm{ml}$ of ANME

535 was isolated and run out for Western blotting. Blots were probed with Xbp1s. GAPDH

536 was used as loading control. Experiments were repeated three times and a representative 537 blot is shown.

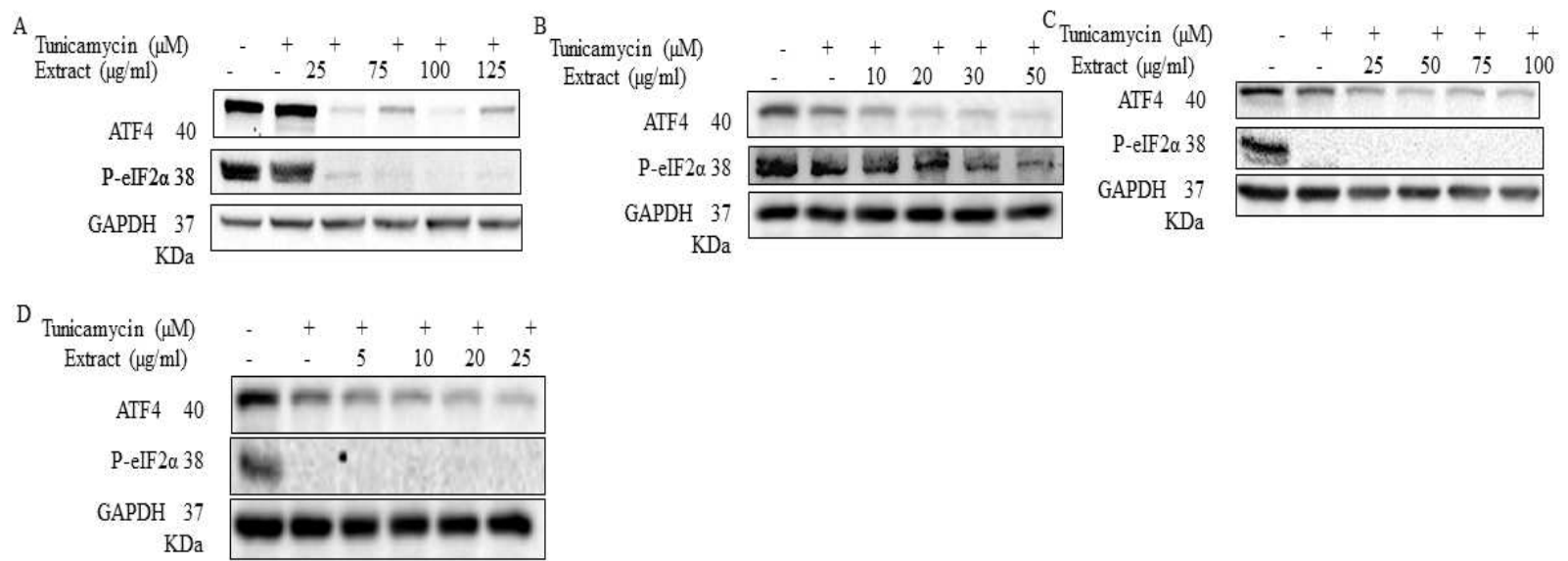


U87MG stimulated with or without $6 \mu \mathrm{M}$ Tunicamycin (4hr) for induction of Unfolded

542 Protein Response followed by treatment with different concentrations in $\mu \mathrm{g} / \mathrm{ml}$ of ANME

543 was isolated and run out for Western blotting. Blots were probed with Xbp1s. GAPDH

544 was used as loading control. Experiments were repeated three times and a representative 545 blot is shown.
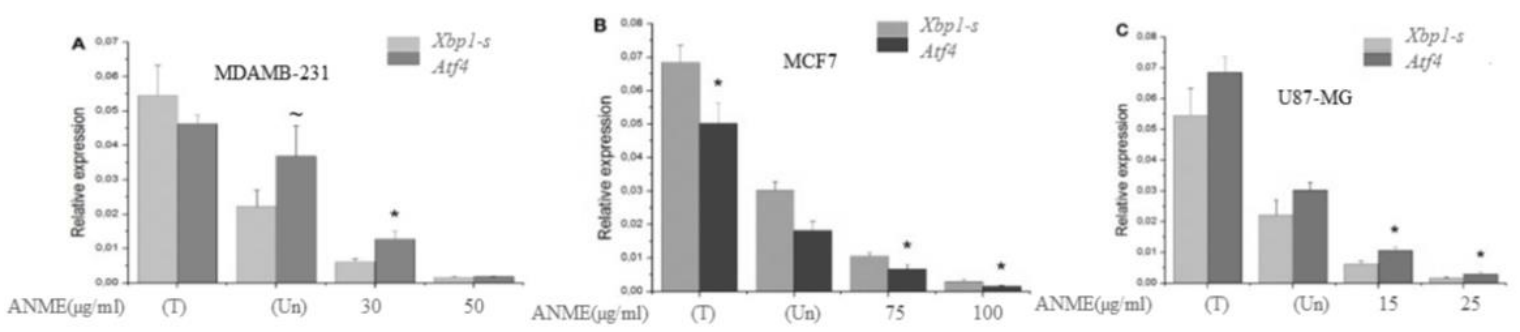

Figure.7: Quantitative real time PCR for relative expression of UPR markers, Xbp1 and ATF4: (A-C) MDAMB-231, MCF 7 and U87-MG . Cells were treated with Tm (6 $\mu \mathrm{g} / \mathrm{ml}$ ) for $4 \mathrm{~h}$ followed by treatment with different concentrations in $\mu \mathrm{g} / \mathrm{ml}$ of ANME. Xbpl and ATF4 mRNA levels were measured by RT-quantitative PCR (qPCR). Measurements were normalized to ACTB mRNA $(n=3)$. $\left({ }^{*}-p<0.05, \sim-p<0.1\right)$.
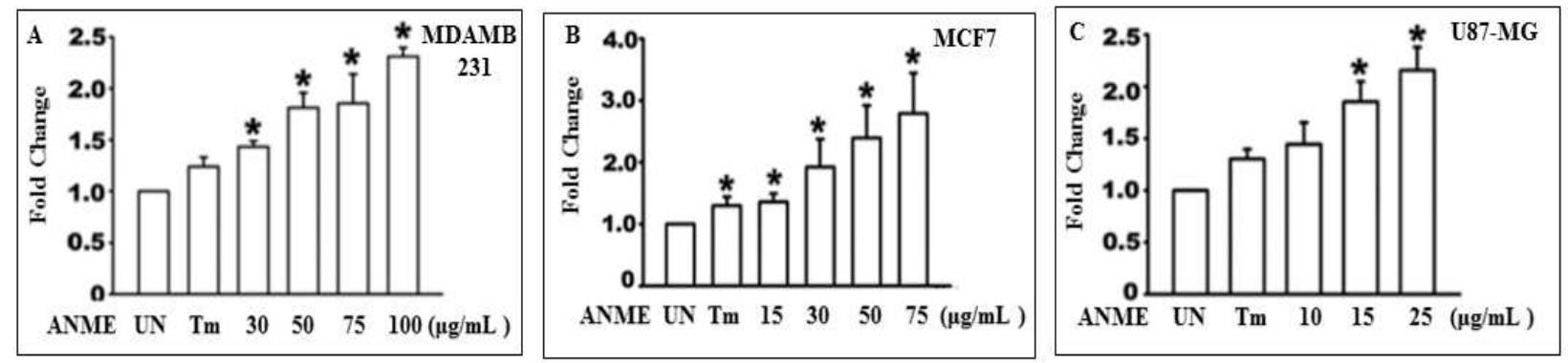

553 Figure.8: Quantitative real time PCR for relative expression of RIDD marker,

554 Blos1S1 (A-C) MDAMB-231, MCF 7 and U87-MG . Cells were treated with Tm (6 $555 \mu \mathrm{g} / \mathrm{ml}$ ) for $4 \mathrm{~h}$ followed by treatment with different concentrations in $\mu \mathrm{g} / \mathrm{ml}$ of ANME. 


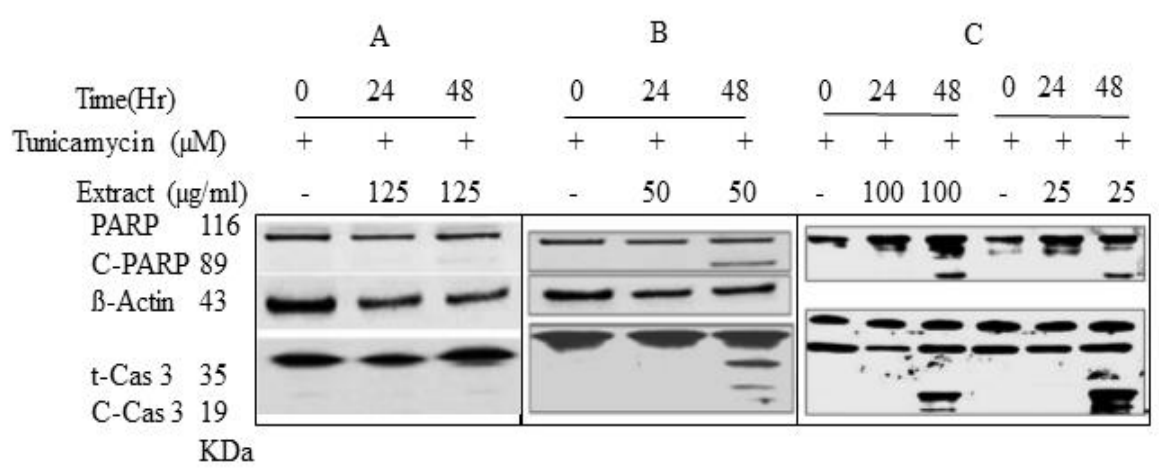

559

560 Figure.9: Activation of caspases by ANME: Protein expression of anti- Caspase 3 and 561 anti- PARP using ANME in (A) HEK- 293T (B) U87 MG (C) MDAMB231 and MCF7 562 cells, resp. Protein extracts of HEK T 293, U87 MG, MDAMB 231 and MCF7 stimulated 563 with or without $6 \mu \mathrm{M}$ Tunicamycin for induction of Unfolded Protein Response followed 564 by treatment with different concentrations of ANME were isolated and run out for 565 Western blotting. Blots were probed with anti- Caspase 3 and anti- PARP. GAPDH was 566 used as loading control. Experiments were repeated three times and a representative blot 567 is shown.

\section{References:}

569 1. Mudasar Ahmad, Zahoor A. Kaloo1, Bashir A. Ganai, Ubaid Yaqoob, Hilal A. Ganaie (2017). Phytochemical Screening of Aquilegia nivalis Flax Jackson: An Important Medicinal Plant of Kashmir Himalaya: A Perspective, Adv. Biomed. Pharma. 4:1, 6-12

2. Chandra Prakash Kala (2006) Medicinal plants of the high altitude cold desert in India: 
575 3. Adamska T, Młynarczyk M, Jodynis-Liebert J, Bylka W, Matławska I, 2003.

576 Hepatoprotective effect of the extract and isocytisoside from Aquilegia vulgaris. $577 \quad$ Phytotherapy research 17(6), 691-696.

578 4. Jadwiga Jodynis-Liebert, Teresa Adamska, Małgorzata Ewertowska, Wiesława Bylka, 579 Irena Matławska, 2009. Aquilegia vulgaris extract attenuates carbon tetrachloride580 induced liver fibrosis in rats, Experimental and Toxicologic Pathology, 61(5) 443$581 \quad 451$.

582 5. Sekena H. A., Aziza A. E., Ibrahim A. B., Mohamed I. M. and Mosaad A. W., 2011. 583 Aquilegia vulgaris extract protects against the oxidative stress and the mutagenic 584 effects of cadmium in Balb/c mice, Experimental and Toxicologic Pathology, 63(4), $585 \quad 337-344$.

586 6. Purushotham, G., Padma, Y., Nabiha, Y. et al. 2016.. In vitro evaluation of anti587 proliferative, anti-inflammatory and pro-apoptotic activities of the methanolic 588 extracts of Andrographis nallamalayana Ellis on A375 and B16F10 melanoma cell $589 \quad$ lines. 3 Biotech (6) 212.

590 7. Younis Mohammad Hazari, Arif Bashir, Ehtisham ul Haq, Khalid Majid Fazili., 2016.

591 Emerging tale of UPR and cancer: an essentiality for malignancy. Tumor Biology, 37, $592 \quad 11,14381-14390$

593 8. Chevet, E., Hetz, C., Samali, A., 2015. Endoplasmic Reticulum Stress-Activated 594 Cell Reprogramming in Oncogenesis. Cancer Discov. 5, 586-597

595 9. Dejeans, N., Barroso, K., Fernandez-Zapico, M.E., Samali, A., Chevet, E., 2015. 596 Novel roles of the unfolded protein response in the control of tumor development 597 and aggressiveness. Semin Cancer Biol. 33, 67-73.

598 10. Hetz, C., Chevet, E., Oakes, S.A., 2015. Proteostasis control by the unfolded $599 \quad$ protein response. Nat Cell Biol. 17, 829-38. 
600 11. Balch, W.E., Morimoto, R.I., Dillin, A., Kelly, J.W., 2008. Adapting proteostasis for 601 disease intervention. Science. 319, 916-9.

602 12. Bartoszewska, S., Collawn, J.F., 2020. Unfolded protein response (UPR) integrated 603 signaling networks determine cell fate during hypoxia. Cell Mol Biol Lett 25, 18 604 13. Schubert, U., Anton, L.C., Gibbs, J., Norbury, C.C., Yewdell, J.W., Bennink, J.R., 605 2000. Rapid degradation of a large fraction of newly synthesized proteins by 606 proteasomes. Nature. 404, 770-4.

607 14. Claudio Hetz and Feroz R. Papa, 2018., The Unfolded Protein Response and Cell Fate 608 Control., Molecular cell, 69, 2, 169-181,

609 15. Samirul Bashir, Mariam Banday, Ozaira Qadri, Arif Bashir, Nazia Hilal, Nida-i-Fatima, 610 Stephen Rader, Khalid Majid Fazili, 2021., The molecular mechanism and functional 611 diversity of UPR signaling sensor IRE1, Life Sciences, , Volume 265, 2021, 118740

612 16. Greenman C, Stephens P, Smith R, Dalgliesh GL et al. 2007. Patterns of somatic 613 mutation in human cancer genomes. Nature. 8; 446(7132),153-8.

614 17. Guichard C, Amaddeo G, Imbeaud S, Ladeiro Y, Pelletier L, Maad IB, Calderaro 615 J, Bioulac-Sage P, Letexier M, Degos F, Clément B, Balabaud C, Chevet E, Laurent 616 A, Couchy G, Letouzé E, Calvo F, Zucman-Rossi J. 2012. Integrated analysis of 617 somatic mutations and focal copy-number changes identifies key genes and 618 pathways in hepatocellular carcinoma. Nat Genet. 44(6), 694-8.

619 18. Parsons DW, Jones S, Zhang X, Lin JC et al. 2008. An integrated genomic analysis 620 of human glioblastoma multiforme. Science. 321(5897),1807-12.

621 19. Ortiz-Urda S, Garcia J, Green CL, Chen L, Lin Q, Veitch DP, Sakai LY, Lee 622 H, Marinkovich MP, Khavari PA. 2005. Type VII collagen is required for Rasdriven human epidermal tumorigenesis. Science. 307(5716), 1773-6. 
Mosaic amplification of multiple receptor tyrosine kinase genes in glioblastoma. Cancer Cell. 20(6), 810-7.

628

629

630

631

632

633

634

635

636

637

638

639

640

641

642

643

644

645

646

647

648

649

650

651

21. Hanahan D, Weinberg RA. 2011. Hallmarks of cancer: the next generation. Cell. 144(5), 646-74.

22. Venditti R, Scanu T, Santoro M, Di Tullio G, Spaar A, Gaibisso R, Beznoussenko GV, Mironov AA, Mironov A Jr, Zelante L, Piemontese MR, Notarangelo A, Malhotra V, Vertel BM, Wilson C, De Matteis MA. 2012. Sedlin controls the ER export of procollagen by regulating the Sar1 cycle. Science. 337(6102), 1668-72.

23. Levental KR, Yu H, Kass L, Lakins JN, Egeblad M, Erler JT, Fong SF, Csiszar K, Giaccia A, Weninger W, Yamauchi M, Gasser DL, Weaver VM. 2009. Matrix crosslinking forces tumor progression by enhancing integrin signaling. Cell. 139(5),891-906.

24. Shi, Z., Yu, X., Yuan, M. et al., 2019., Activation of the PERK-ATF4 pathway promotes chemo-resistance in colon cancer cells. Sci Rep 9, 3210

25. Hart LS, Cunningham JT, Datta T, Dey S, Tameire F, Lehman SL, Qiu B, Zhang H, Cerniglia G, Bi M, Li Y, Gao Y, Liu H, Li C, Maity A, Thomas-Tikhonenko A, Perl AE, Koong A, Fuchs SY, Diehl JA, Mills IG, Ruggero D, Koumenis C. 2012, ER stress-mediated autophagy promotes Myc-dependent transformation and tumor growth. J Clin Invest.,122, 12, 4621-34.

26. Rozpedek W, Pytel D, Mucha B, Leszczynska H, Diehl JA, Majsterek I. The Role of the PERK/eIF2 $\alpha /$ ATF4/CHOP Signaling Pathway in Tumor Progression During Endoplasmic Reticulum Stress. Curr Mol Med. 2016;16(6):533-44.

27. Huber AL, Lebeau J, Guillaumot P, Pétrilli V, Malek M, Chilloux J, Fauvet F, Payen L, Kfoury A, Renno T, Chevet E, Manié SN.,2013, p58(IPK)-mediated attenuation of the proapoptotic PERK-CHOP pathway allows malignant progression upon low glucose. Mol Cell, 49, 6, 1049-59. 
652

653

654

655

656

657

658

659

660

661

662

663

664

665

666

667

668

669

670

671

672

673

674

675

676

28. Arif Bashir, Younis Hazari, Debnath Pal, Dibyajyoti Maity, Samirul Bashir, Laishram Rajendrakumar Singh, Naveed Nazir Shah, Khalid Majid Fazil, 2020., Aggregation of M3 (E376D) variant of alpha1- antitrypsin. Sci Rep 10, 8290

29. Anderson D. J. et al. 2015. Targeting the AAA ATPase p97 as an approach to treat cancer through disruption of protein homeostasis. Cancer Cell (28), 653-665.

30. Chou TF. 2011. Reversible inhibitor of p97, DBeQ, impairs both ubiquitindependent and autophagic protein clearance pathways. Proc. Natl. Acad. Sci. USA (108), 4834-4839.

31. Benosman S. 2013 Interleukin-1 receptor-associated kinase-2 (IRAK2) is a critical mediator of endoplasmic reticulum (ER) stress signaling. PloS one 8; e64256.

32. Tam AB. Koong AC. \& Niwa M. 2014. Ire1 has distinct catalytic mechanisms for XBP1/HAC1 splicing and RIDD. Cell reports (9, 850-858.

33. Hamid Bakshi, Smitha Sam, Roya Rozati, Phalisteen Sultan, Tajamul Islam, Babita Rathore, Zahoor Lone, Manik Sharma, Jagrati Triphati, Ramesh Chand Saxena, 2010. DNA fragmentation and cell cycle arrest: a hallmark of apoptosis induced by crocin from kashmiri saffron in a human pancreatic cancer cell line; Asian Pac J Cancer Prev. 2010;11(3):675-9.

34. Albrahim T \& Alnasser M \& Al-Anazi, Mashael \& Alkahtani, Muneera \& Alkahtani, Saad \& Al-Qahtani, Ahmed. 2020. Potential anti-inflammatory and anti-apoptotic effect of Coccinia grandis plant extract in LPS stimulated-THP-1 cells. Environmental Science and Pollution Research. 27. 10.1007/s11356-020-08445-5.

35. Ashok Singh, Manohar Lal \& S. S. Samant (2009) Diversity, indigenous uses and conservation prioritization of medicinal plants in Lahaul valley, proposed Cold Desert Biosphere Reserve, India, International Journal of Biodiversity Science \& Management, 5:3, 132-154 
677 36. Ewertowska M, Jodynis-Liebert J, Kujawska M, Adamska T, Matławska I, Szaufer678 Hajdrych M., 2009, Effect of Aquilegia vulgaris (L.) ethyl ether extract on liver antioxidant defense system in rats. Int J Occup Med Environ Health, 22(2):115-23.

37. Marina Potest, Antonella Minutolo, Angelo Gismondi, Lorena Canuti, Maurice Kenzo, Valentina Roglia, Federico Macchi, Sandro Grelli, Antonella Canini, Vittorio Colizzi, Carla Montesano. 2019. Cytotoxic and apoptotic effects of different extracts of Moringa oleifera Lam on lymphoid and monocytoid cells, Experimental and Therapeutic Medicine, 5-17

38. Li, S., Pasquin, S., Eid, H. M., Gauchat, J. F., Saleem, A., \& Haddad, P. S. 2018. Antiapoptotic potential of several antidiabetic medicinal plants of the eastern James Bay Cree pharmacopeia in cultured kidney cells. BMC complementary and alternative medicine, 18(1), 37.

39. Kowalczyk, T., Sitarek, P., Skała, E., Toma, M., Wielanek, M., Pytel, D., Wieczfińska, J., Szemraj, J., \& Śliwiński, T. 2019. Induction of apoptosis by in vitro and in vivo plant extracts derived from Menyanthes trifoliata L. in human cancer cells. Cytotechnology, 71(1), 165-180.

40. Fribley, A., Zhang, K., \& Kaufman, R. J. (2009). Regulation of apoptosis by the unfolded protein response. Methods in molecular biology (Clifton, N.J.), 559, 191204. https://doi.org/10.1007/978-1-60327-017-5_14

41. Raffaella Iurlaro and Cristina Munoz-Pinedo.2016. Cell death induced by endoplasmic reticulum stress, FEBS Journal 283, 2640-2652

42. Bartoszewska, S., Collawn, J.F. 2020. Unfolded protein response (UPR) integrated signaling networks determine cell fate during hypoxia. Cell Mol Biol Lett (25), 18 allosteric control of the IRE1alpha endoribonuclease using kinase inhibitors. Nat Chem Biol. (8), 982-9. 
44. Bouchecareilh M, Higa A, Fribourg S, Moenner M, Chevet E. 2011. Peptides derived from the bifunctional kinase/RNase enzyme IRE1alpha modulate IRE1alpha activity and protect cells from endoplasmic reticulum stress. FASEB J. (25),311529.

45. Arvin B. Tam, Lindsay S. Roberts, Vivek Chandra, Io Guane Rivera, Daniel K. Nomura, Douglass J. Forbes, Maho Niwa 2018, The UPR Activator ATF6 Responds to Proteotoxic and Lipotoxic Stress by Distinct Mechanisms . Developmental Cell $46,327-343$

46. Anna Shemorry, Jonathan M Harnoss, Ofer Guttman, Scot A Marsters, László G Kőműves, David A Lawrence, Avi Ashkenazi (2019) Caspase-mediated cleavage of IRE1 controls apoptotic cell commitment during endoplasmic reticulum stress eLife 2019;8:e47084

47. Anna Walczak, Kinga Gradzik, Jacek Kabzinski, Karolina Przybylowska-Sygut, Ireneusz Majsterek, 2019, The Role of the ER-Induced UPR Pathway and the Efficacy of Its Inhibitors and Inducers in the Inhibition of Tumor Progression, Oxidative Medicine and Cellular Longevity, 2019, 5729710, 1-15

48. Emma Madden, Susan E. Logue, Sandra J. Healy, Serge Manie, Afshin Samali, 2019. The role of the unfolded protein response in cancer progression: From oncogenesis to chemoresistance, Biology of the Cell, 111,1,1-17.

49. Upton JP, Wang L, Han D, Wang ES, Huskey NE, Lim L, Truitt M, McManus MT, Ruggero D, Goga A, Papa FR, Oakes SA. 2012. IRE1a cleaves select microRNAs during ER stress to derepress translation of proapoptotic Caspase-2. Science. 338, 6108, 818-22.

50. Bi M, Naczki C, Koritzinsky M, Fels D, Blais J, Hu N, Harding H, Novoa I, Varia M, Raleigh J, Scheuner D, Kaufman RJ, Bell J, Ron D, Wouters BG, Koumenis C.,2005. ER 
728 stress-regulated translation increases tolerance to extreme hypoxia and promotes

729 tumor growth. EMBO J. 24, 19

730 


\section{Figures}
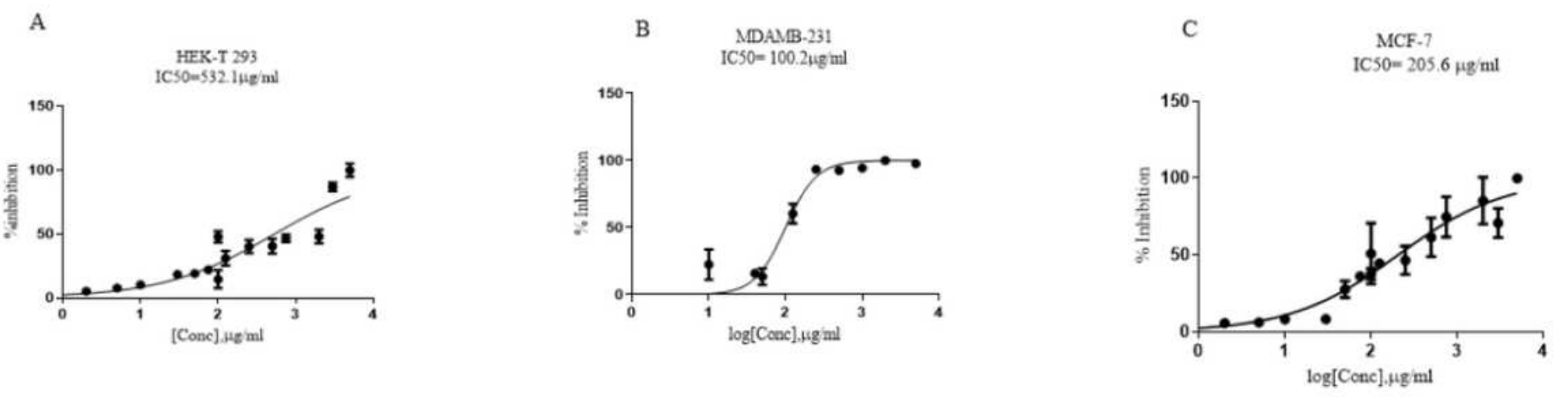

D
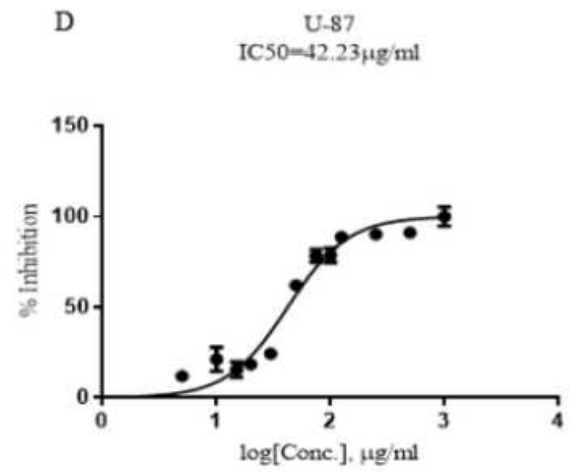

\section{Figure 1}

Effect of ANME on (A)HekT293 (B) MDAMB-231(C) MCF7 and (D) U87MG 2 cells in various concentrations $(1-2000 \mu \mathrm{g} / \mathrm{mL})$ after 24 hours; determined using MTT cell viability assay: Dose-response curves of ANME was determined using MTT cell viability assay. IC50 values were calculated as mean values from three independent experiments by nonlinear regression using Graph pad Prism $® 6$ software. Percentage inhibition of untreated cells was assumed to be zero. 
A

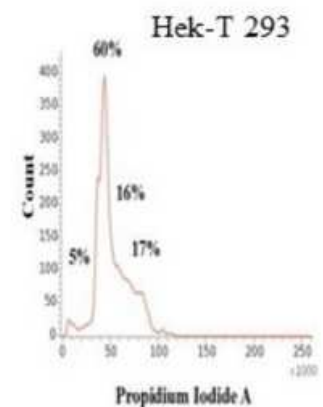

C

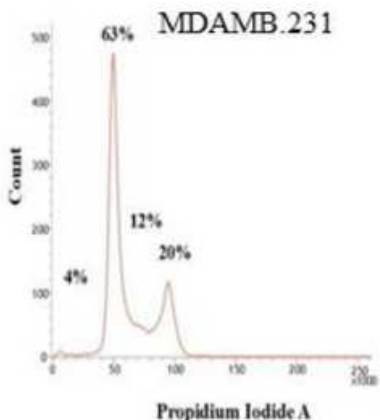

Hek-T 293
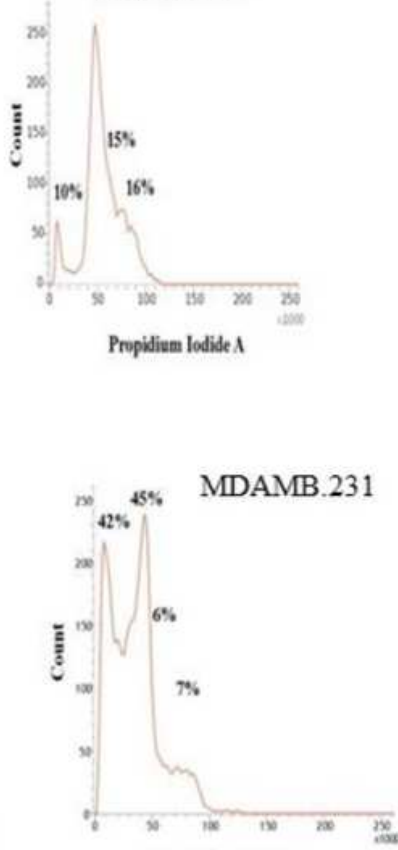

Propidium lodide A
B

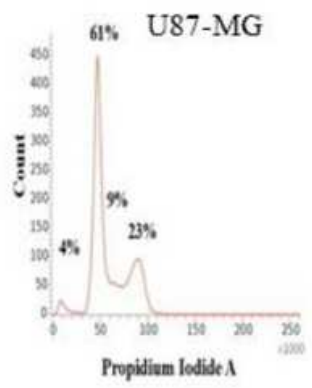

D

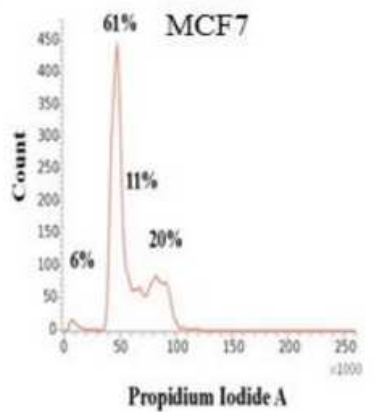

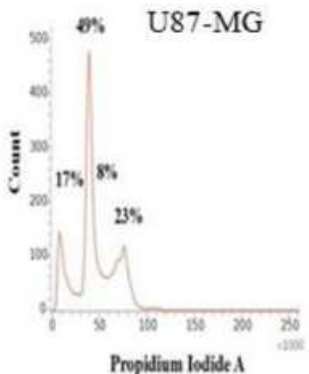

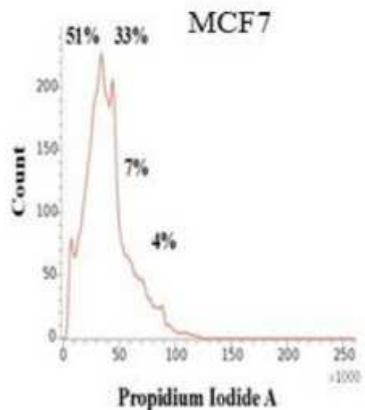

\section{Figure 2}

Cell cycle analysis: (A-D) Hek293T, U87, MDAMB-231 and MCF 7 cell lines were treated with different concentrations of ANME for 24 hrs and cells were fixed and stained with propidium iodide and analyzed by flow cytometry. The mean values \pm SD were calculated from three different experiments. $p<0.05$ with respect to control.

A

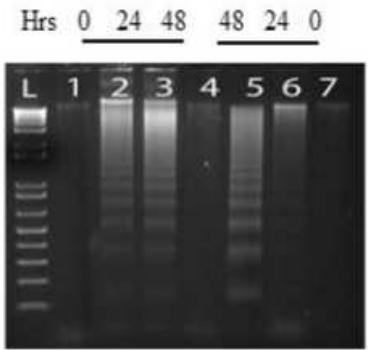

- Lane 1,2 and 3=ANME treatment for 0,24 and 48 hours in U87-MG

- Lane 7,6 and 5=ANME treatment for 0,24 and 48 hours in Hek293
B

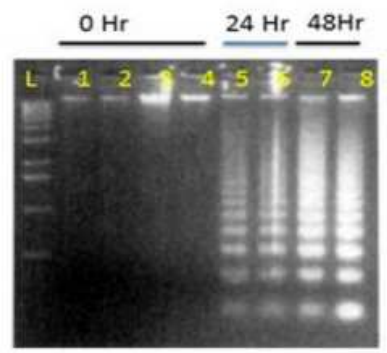

- Lane 1 and $2=$ ANME treatment for 0 hours in MDAMB and Lane 3 and $4=$ ANME treatment for 0 hours in MCF7
0

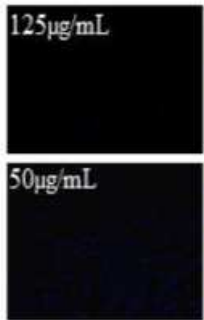

$100 \mu \mathrm{g} / \mathrm{mL}$

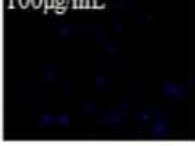

$25 \mu \mathrm{gmL}$

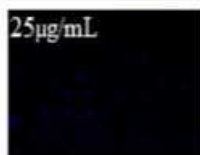

24

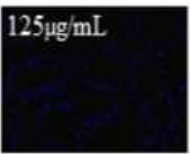

$50 \mu \mathrm{g} / \mathrm{mL}$

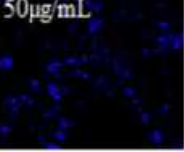

$100 \mu \mathrm{g} m \mathrm{~mL}$

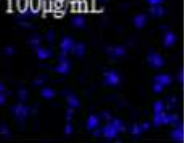

$25 \mu \mathrm{g} / \mathrm{mL}$

48 (Hours)

$125 \mu \mathrm{g} \mathrm{mL}$

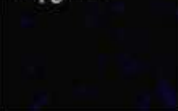

$50 \mu \mathrm{g} / \mathrm{mL}$

MDAMB-231

$100 \mu \mathrm{g} / \mathrm{mL}$

MCF7

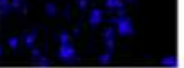

$25 \mu \mathrm{g} / \mathrm{mL}$

U87-MG 
(A) Time dependent DNA fragmentation: DNA Laddering in (a) U87- MG and HEK-T293 cells (b) MDAMB231 and MCF7 cells resp. ANME extract induces DNA fragmentation in all the cell line panels stimulated with or without $6 \mu \mathrm{M}$ Tunicamycin(4hr) for induction of Unfolded Protein cells. The cells were treated with different concentrations $(\mu \mathrm{g} / \mathrm{ml})$ of extract for every cell type for 0,24 and $48 \mathrm{~h}$. Cells from each sample were harvested for DNA gel electrophoresis as described; (B)Formation of apoptotic bodies in time dependent manner, DAPI staining:Morphological and nuclear changes induced by ANME. HEKT293, MDAMB, MCF7 and U87-MG cells after treatment with different concentration for each cell type induced various nuclear changes such as chromatin condensation, nuclei condensation, and nuclear degradation, as demonstrated by DAPI staining at 400x in time dependent manner. However Hek293 showed only inhibition in cell growth with no signs of apoptosis; ANME=Aquilegia nivalis methanolic extract.

A

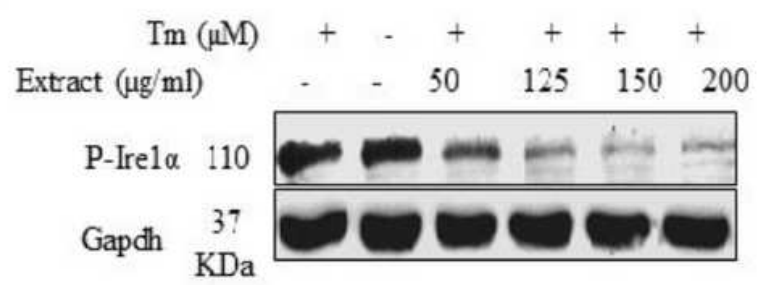

$\mathrm{C}$

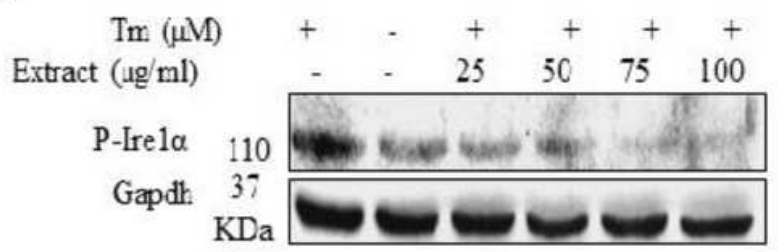

B

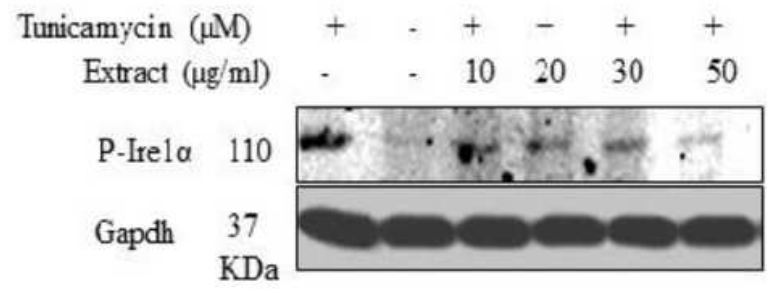

D

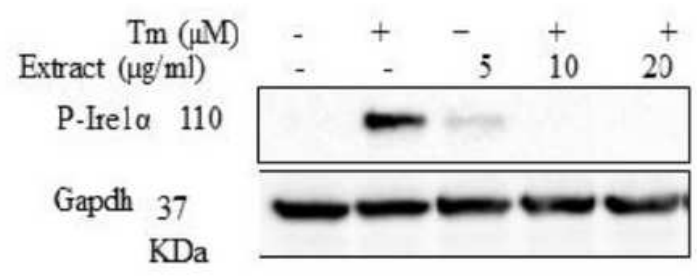

\section{Figure 4}

Immunoblot analysis for p-Ire1a in (A) Hek293T (B) MDAMB 231(C) MCF 7 (D) U87 MG: Protein extracts of Hek T 293, MDAMB 231, MCF 7 and U87MG stimulated with or without $6 \mu$ M Tunicamycin (4hr) for induction of Unfolded Protein Response followed by treatment with different concentrations in $\mu \mathrm{g} / \mathrm{ml}$ of ANME was isolated and run out for Western blotting. Blots were probed with p-Ire1 a. GAPDH was used as loading control. Experiments were repeated three times and a representative blot is shown. 
A

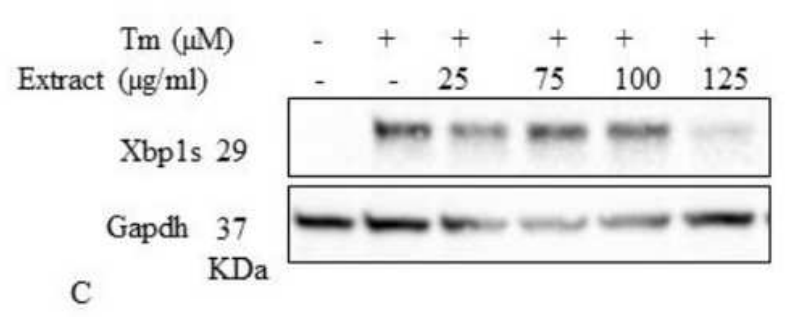

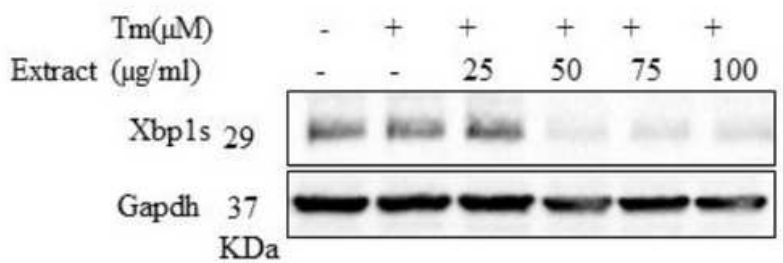

B

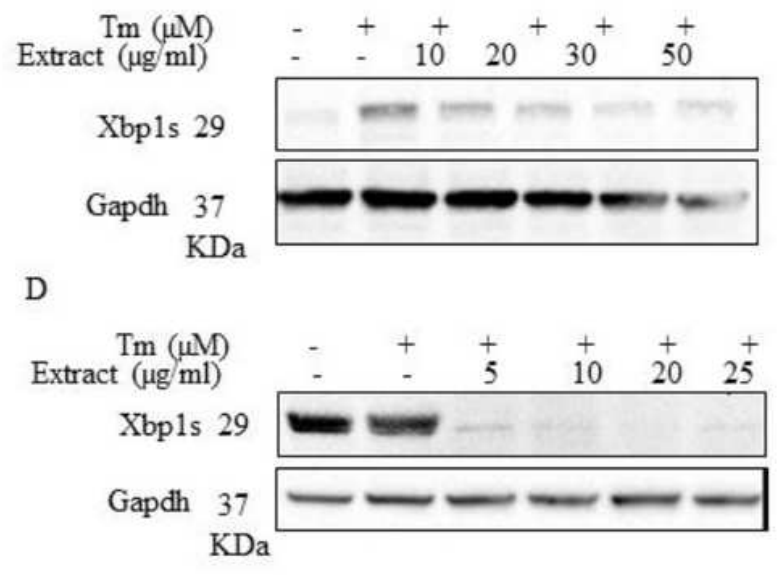

Figure 5

Immunoblot analysis for Xbp1-s in (A) Hek293T (B) MDAMB 231(C) MCF 7 (D) U87 MG: Protein extracts of Hek T 293, MDAMB 231, MCF 7 and U87MG stimulated with or without $6 \mu$ M Tunicamycin (4hr) for induction of Unfolded Protein Response followed by treatment with different concentrations in $\mu \mathrm{g} / \mathrm{ml}$ of ANME was isolated and run out for Western blotting. Blots were probed with Xbp1s. GAPDH was used as loading control. Experiments were repeated three times and a representative blot is shown.

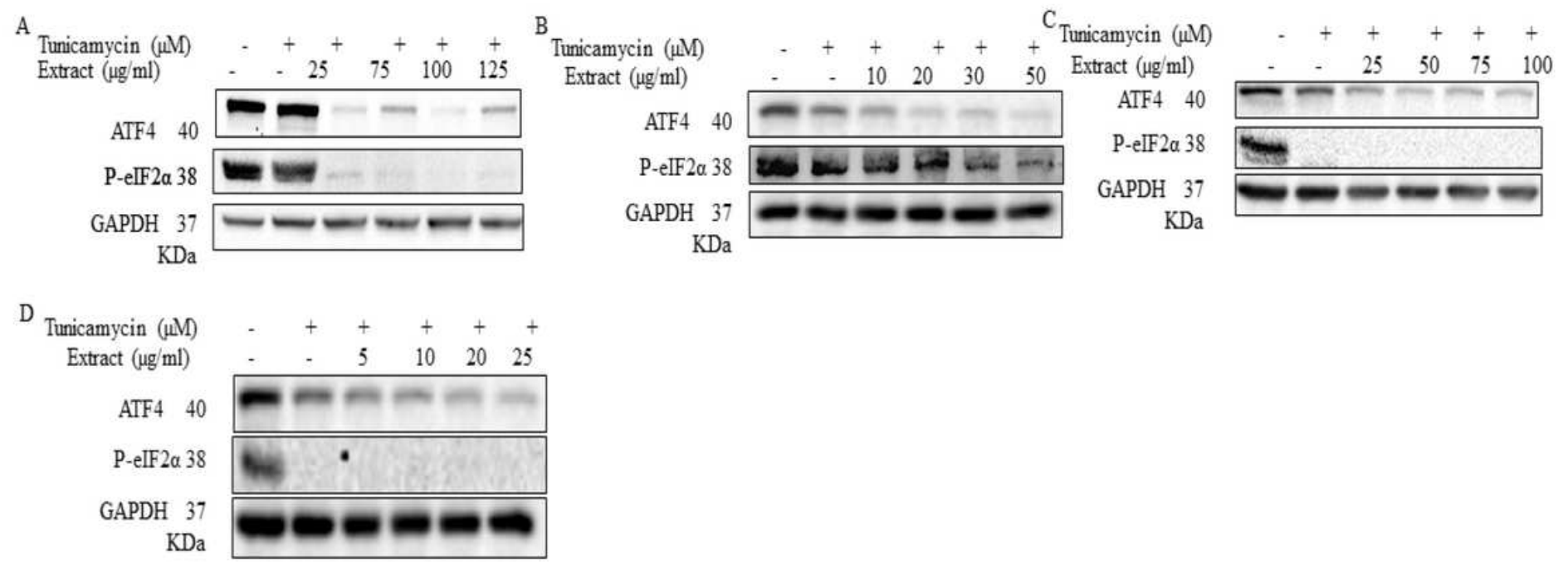

Figure 6

Immunoblot analysis for p-elF2a and ATF4 (A) Hek293T (B) MDAMB 231(C) MCF 7 (D) U87 MG: Protein extracts of Hek T 293, MDAMB 231, MCF 7 and U87MG stimulated with or without $6 \mu$ M Tunicamycin (4hr) for induction of Unfolded Protein Response followed by treatment with different concentrations in 
$\mu \mathrm{g} / \mathrm{ml}$ of ANME was isolated and run out for Western blotting. Blots were probed with Xbp1s. GAPDH was used as loading control. Experiments were repeated three times and a representative blot is shown.
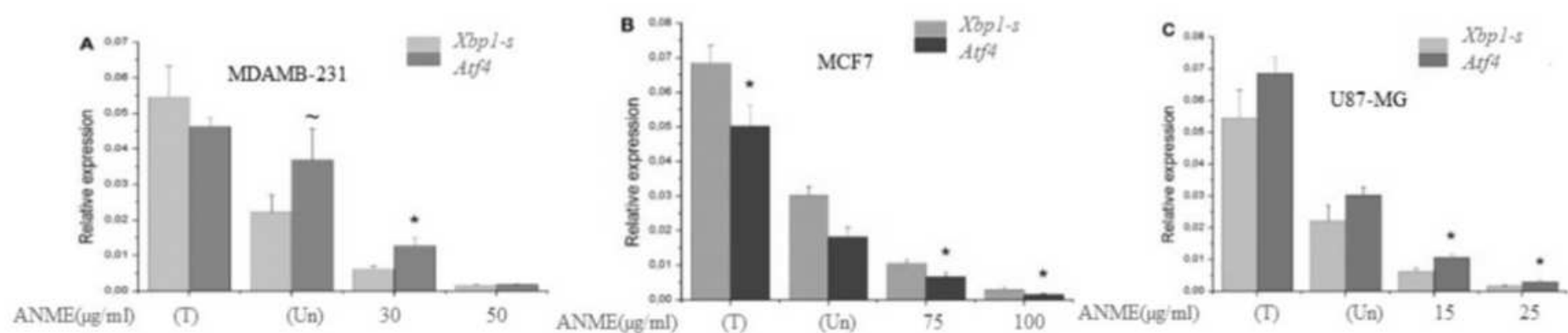

Figure 7

Quantitative real time PCR for relative expression of UPR markers, Xbp1 and ATF4: (A-C) MDAMB-231, MCF 7 and U87-MG . Cells were treated with $\mathrm{Tm}(6 \mu \mathrm{g} / \mathrm{ml})$ for $4 \mathrm{~h}$ followed by treatment with different concentrations in $\mu \mathrm{g} / \mathrm{ml}$ of ANME. Xbp1 and ATF4 mRNA levels were measured by RT-quantitative PCR (qPCR). Measurements were normalized to ACTB mRNA $(n=3) .\left({ }^{*}-p<0.05, \sim-p<0.1\right)$.
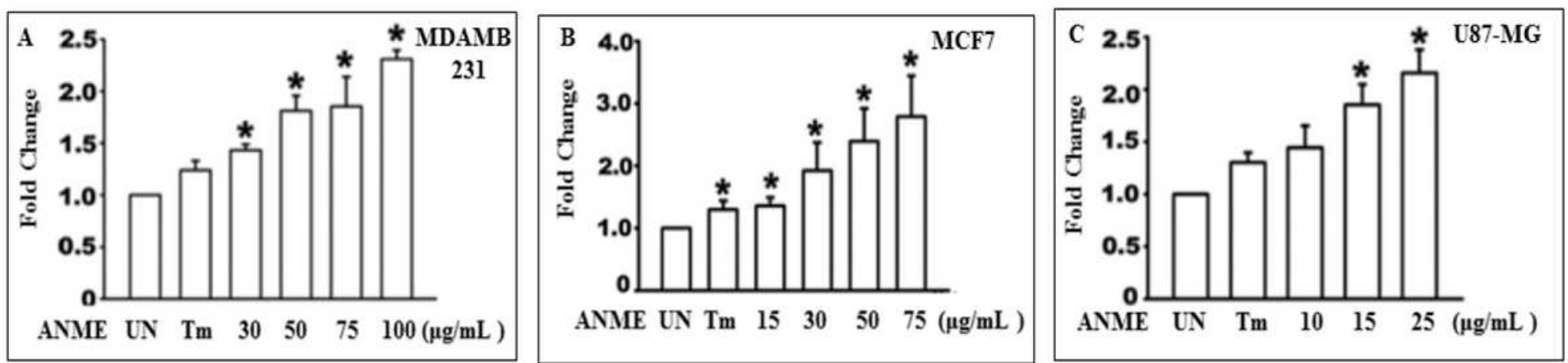

Figure 8

Quantitative real time PCR for relative expression of RIDD marker, Blos1S1 (A-C) MDAMB-231, MCF 7 and U87-MG . Cells were treated with $\mathrm{Tm}(6 \mu \mathrm{g} / \mathrm{ml})$ for $4 \mathrm{~h}$ followed by treatment with different concentrations in $\mu \mathrm{g} / \mathrm{ml}$ of ANME. Blos1S1mRNA levels were measured by RT-quantitative PCR (qPCR). Measurements were normalized to ACTB mRNA $(n=3) .\left({ }^{*}-p<0.05\right)$. 


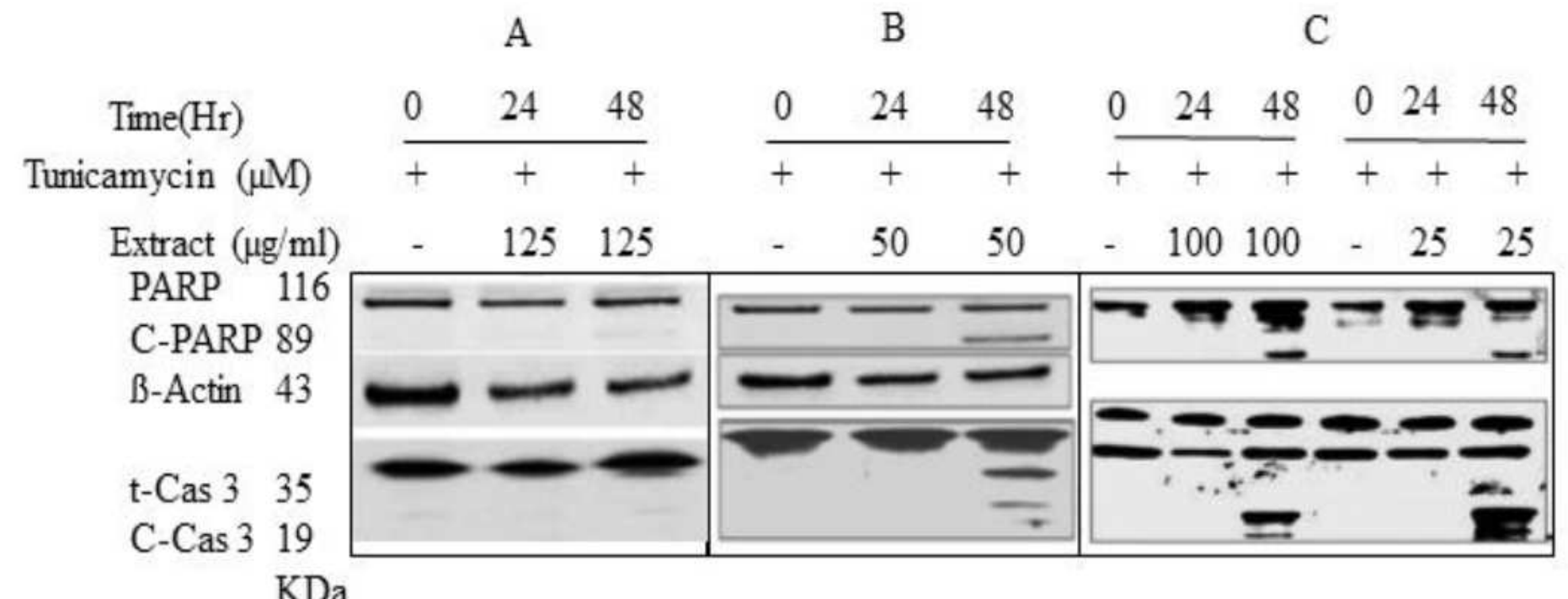

\section{Figure 9}

Activation of caspases by ANME: Protein expression of anti- Caspase 3 and anti- PARP using ANME in (A) HEK-293T (B) U87 MG (C) MDAMB231 and MCF7 cells, resp. Protein extracts of HEK T 293, U87 MG, MDAMB 231 and MCF7 stimulated with or without $6 \mu \mathrm{M}$ Tunicamycin for induction of Unfolded Protein Response followed by treatment with different concentrations of ANME were isolated and run out for Western blotting. Blots were probed with anti- Caspase 3 and anti-PARP. GAPDH was used as loading control. Experiments were repeated three times and a representative blot is shown. 